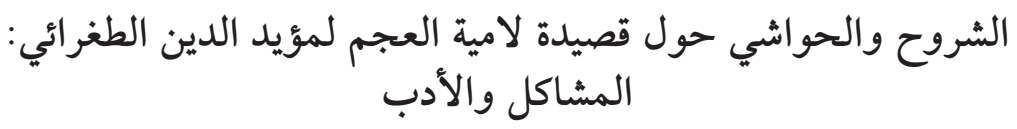

\title{
Müeyyidüddîn et-Tuğrâî̀nin Lâmiyyetü’l-Acem Adlı Kasidesi Üzerine Yazılmış Şerh-Hâşiye Geleneği: Problemler ve Literatür
}

\author{
Tradition of Commentary and Gloss on Mu' ayyid al-Dīn al- \\ Ṭughrā' ì̀s Lämiyyat al- 'Ajam: Problems and Literature
}

\section{Mehdi CENGİZ*}

Öz: Hükümdarın isim ve sıfatlarını içeren tuğraya nispetle Tuğrâî olarak tanınan Selçuklu devleti vezirlerinden Hüseyin b. Ali’nin (ö. 515/1121) yazdığı Lâmiyyetü’l-acem isimli kaside, şairin kullandığı edebî sanatlar ve şiirin muhtevasıyla Arapça yazılmış kasideler arasında öne çıar. Neden kasidenin Lâmiyyetü'l-acem adiyla meşhur olduğu sorusuna farklı cevaplar verilse de genellikle bu kaside, muhteva ile içerdiği hikmetler açısından Cahiliye şairi Şenferânın (ö. 525-550) Lâmiyyetüll-arab’nna benzetilmiş ve bu çerçevede Tuğrâînin, Lâmiyyetü'l-acem'i Lâmiyyetü'l-arab'a mukabil olarak nazmettiği öne sürülmüştür. Tuğrâî mezkûr kasidesinin ilk beyitlerinde kendini över, akabinde görevinden azledilmesi sonucunda Bağdat'tan ayrılmasından, bu ayrılışın onun üzerindeki etkisinden ve başına gelen olaylardan şikâyet eder. Daha sonra sevgilisine yaptığı yolculuğu anlatır, kasidenin sonunda şikâyet ve nasipsizlik çerçevesinde karşılaştıklarından yakınıp zorluklara teslim olmamaya vurgu yapar. Yazıldığı dönemden günümüze uzanan süreçte Tuğrâînin bu kasidesi üzerine pek çok çalışma yapılmıştır. Bunların bir kısmı taştîr, tahmîs ve muâraza gibi yeni şiir oluşturma metotları ile ilgiliyken bazıları da şerh ve haşiye gibi ana metni anlayıp çeşitli açılardan tenkit etmeye yöneliktir. Lâmiyyetü’l-acem etrafında kaleme alınan bu çalışmalar, asırlar boyunca devam eden bir edebiyat geleneği oluşmuştur. Fakat kaside üzerine yazılan şerh, hâşiye ve muhtasarların ilişkiler ağı tespit edilmediğinden bunların birbiriyle ilgisi ve Lâmiyyetü'l-acem şerh-hâşiye geleneğindeki yeri belirlenememiştir. Bu çerçevede Lâmiyyetü'l-acem üzerine yazılan eserleri tespit etmeye çalışan Kâtib Çelebi’nin (ö. 1067/1657) Keşfü'z-zunûn'u, Brockelmann’ın (ö. 1956) Geschichte der Arabischen Litteratur'ü, Habeşînin Câmi'u'ş-şurûh ve’lhavâşîsi, Ahmed Muhammed Mansûr'un Şurûhu Lâmiyyeti'l-acem'i ve Ali Cevad Tahir'in (ö. 1996) et-Tuğrâ̂̀, hayâtuhu, şi 'ruhu, Lâmiyyetuhu (bahs ve tahkîk ve tahlîl) adlı çalışması önem arz etmektedir. Fakat bu kitaplar kaside üzerine yazılan şerh ve hâş̧iyeleri tespitte yetersiz olduğu gibi Lâmiyyetü'l-acem'in yaygın etkisinden ve literatürdeki ilişkiler ağından da bahsetmemektedir. İlgili literatürdeki ilişkiler hususunda yaygın etkisi

* Dr. Öğr. Üyesi, Artvin Çoruh Üniversitesi İlahiyat Fakültesi Arap Dili ve Belagatı Anabilim Dalı. mehdicengiz@ artvin.edu.tr

ORCID: 0000-0001-7593-1801 
ve diğer çalışmalar arasındaki merkezî konumundan dolayı Salahaddin es-Safedînin (ö. 764/1363) Gaysü'l-edeb ellezî inseceme bi-şerhi Lâmiyyeti'l-acem adlı şerhi önemli bir yer tutmaktadır. Safedî bu şerhte tercüme tekniklerinden astronomiye, İslâm hukukundan dil ilimlerine kadar pek çok disiplinle ilgili ayrıntıya yer vermiştir. Ayrıca bu eserde Safedî, Tuğrâînin beyitlerindeki lafız ve anlam sirkatlerini tespit edip diğer şiirleriyle karşlaştırmıştır. Kasideyle doğrudan ilgisi olmayan istitradi bilgileri zikretmeyi ilke olarak benimseyen Safedînin bu şerhi, aynı zamanda önemli bir şiir antolojisi özelliği taşır. Cahiliyeden kendi dönemine kadar pek çok şairin çeşitli beyitlerinin yer aldığı bu çalışmada Safedî, kendi nazmettiği şiirleri de zaman zaman zikreder. Bu kitapta yer verdiği hikâyelerdeki bazı unsurlar müstehcen kabul edilip bunların zikredilmesinin uygun olmadığı söylenmiștir. Bununla beraber Safedînin şerhinden sonra kaleme alınan eserlerin büyük çoğunluğu bu kitabı esas almış ve edebiyat münekkitleri bu şerh üzerine pek çok tenkit, hâşiye ve ihtisar çalışması yapmıştır. Daha açık bir ifadeyle Safedînin bu eserinden sonra yapılan çalışmaların hemen hiçbiri bu şerhe atıf yapmadan geçmemiştir. Nitekim Tuğrâînin kasidesi üzerine çalışma yapan onlarca müellif arasından yalnızca Safedîye "Lâmiyyetü’l-acem Şarihi” denilmiştir. Safedînnin bir tarihçi ve edebiyat münekkiti olması ve bunu mezkûr şerhine yansıtması yazdığı şerhin hacmini bir hayli artmıştır. Bu çerçevede Kemaleddin ed-Demîrî (ö. 808/1405), Safedînin, konuyla doğrudan ilgili olmayan uzun istitrâdlar yaptığını ifade edip bu şerhi el-Maksadü'l-etem fî şerhi Lâmiyyeti'l-acem adıyla ihtisar etmiştir. Çeşitli baskıları yapılan bu eserde ayet ve hadislerden çeşitli iktibaslar yer almaktadır. Benzer gerekçelerle Muhammed b. Abbas el-Bedrânî (ö. 763/1555), Celaledddin el-Mahallî (ö. 864/1459) ve birçok âlim Safedînin şerhini ihtisar etmiştir. Bunun yanında Bedrüddin ed-Demâmînî (ö. 827/1424), Nüzûlü̉l-Gays ellezî inseceme alâ şerhi Lâmiyyeti'l-acem ismiyle Safedînin şerhini ağır sözlerle eleştiren bir tenkit çalışması kaleme almıştır. İbn Akbers olarak bilinen Ali b. Muhammed b. Akbers (ö. 862/1458) ise Tahkîmü'l-ukûl bi-ufûli’l-Bedr fi’n-nüzûl adlı kitabında Safedînin kitabının hatasız olmadığını fakat Demâmînînin eleştirinin dozunu kaçırdığını ifade edip iki müellifin görüşlerini karşılaştırmıştır. Çoğunlukla Safedînin söylediklerini savunan İbn Akbers yer yer Demâmînînin eleştirilerini de haklı bulur. Lâmiyyetü'l-acem üzerine kaleme alınan şerh ve hâşiyeler arasında sadece Safedînnin şerhi müstakil bir gelenek oluşturmuş, Celal b. Hızır (ö. 966/1559'dan sonra) ve Ebû Cumánın (ö. 1016/1607'dan sonra) şerhleri üzerine de çeşitli çalışmalar yapılmıştır. Mehmed Lebîb Efendi’nin (ö. 1284/1867) kaleme aldığı Şerhu Lâmiyyeti'l-acem adlı şerh, Osmanlıca yazılmış olup Safedînin yukarıda zikredilen eseri başta olmak üzere diğer şerhlerden yararlanılarak hazırlanan çeviri-şerh mahiyetinde bir çalışmadır. Bu makale Lâmiyyetül-acem üzerine oluşan şerh-hâş̧iye literatürünü ve bu literatürün çeşitli problemlerini konu edinmektedir. Bu doğrultuda makalenin ilk bölümünde Tuğrâînin Lâmiyyetü'l-acem’i hakkında bilgi verilecek, ikinci bölümde ise kaside üzerine neden şerh ve hâsşiye kaleme alındığı ve bu eserlerde hangi konuların tartışıldığı sorularına cevap aranacaktır. Ayrıca bu bölümde ilgili literatür içerisinde önemli görülen eserler de değerlendirilecektir. Son bölümde ise tespit edilen literatür kategorize edilip bulundukları el yazma kütüphanelerine ve zikredildikleri kaynaklara yer verilecektir. Fakat bunlardan önce Lâmiyyetü'l-acem literatürünü tespit etmeye çalışan veya bu gelenek hakkında bilgi veren klasik ve modern kaynakları değerlendirip bu çalışmayı diğerlerinden ayıran temel özelliklere işaret edilecektir.

Anahtar kelimeler: Tuğrâî, Lâmiyyetü’l-acem, şerh, hâşiye, Büyük Selçuklu Devleti

Abstract: The ode named Lāmiyyat al- 'Ajam, written by al-Ḥusayn b. 'Alī al-Ṭghrā̄ì (d. 515/1121), one of the Saljükid wazìrs, has stood out among other odes with the rhetorical devices used by the poet and the content of the poetry. Therefore, many commentaries 
(sharh) and annotations (häshiya) had been written on the ode. However, since these works were not identified, their relationship with each other and the common effects of these works in the world of literature could not be examined. Without determining the network of commentary, annotation, and specialists, neither the original text nor the widespread influence of commentary and annotation written on this text can be determined. In this context, the books that try to identify the works written on the named Lāmiyyat al- 'Ajam like Kashf al-ẓunùn 'an asāmi al-kutub wa al-funūn of Kàțīb Shalabī byname Ḥājjì Khalîfa (d. 1067/ 1657), Brockelmann's (1868-1956) Geschichte der arabischen Litteratur, known as GAL, Jāmi' al-shurūh wa al-hawāshī of al-Habashī and Shurūh Lāmiyyat al-Ajam of Aḥmad Muhammad al-Manșūr and 'Alī Jawād Ṭāhir's (d. 515/1121) al-Ṭghrā' '̄: hayātuhu, shi 'ruhu, lāmiyyatuhu are important. However, these books are insufficient in determining the commentary and annotations written on the ode, as well they do not mention the widespread influence of these works and the network of the literature. Among the works written on Lämiyyat al- 'Ajam, the commentary Ghayth al-adab alladhì insajama bi sharh Lämiyyat al- 'Ajam written by Khalì b. Aybak al-Șafadī is very important due to its widespread influence and central position in the literature network. The vast majority of the works written after this commentary were based on this book, and literary scholars have done many critical annotation and abridgment (mukhtașar) studies on this commentary. More clearly, almost none of the studies made after this work of al-Șafadi have passed without reference to it. As a matter of fact, among the dozens of authors who worked on this ode, only al-Ṣafadi has been called Làmiyyat al- 'Ajam commentator. Muhammad al-Damīrì (d. 808/1405), who stated that al-Ṣafadi made long digressions unrelated to the subject, abridged in this commentary under the name al-Maqșad al-atamm sharh Lamiyyat al- 'Ajam (Mukhtasar sharh Lämiyyat al- 'Ajam), Muḥammad al-Badrāni (d. 763/1555), Jalāl al-Dīn alMahalli (d. 864/1459) and many scholars have specialized in the mentioned commentary of al-Șafadī. In addition, Badr al-Dìn al-Damāminnì (d. 827/1424), penned a heavy criticism to al-Ṣafadīs commentary with the name of Nuzūl al-ghayth alladhì insajama 'alá sharh Lāmiyyat al- 'Ajam. 'Alī b. Moḥammad (d. 862/1458), known as Ibn Aqbars, in his book Tahkim al- 'uqūl bi-ufül al-Badr fì al-Nuzūl, has compared the views of the two authors, stating that al-Șafadīs book is not flawless, but al-Damāminnì has gone beyond the limit of criticism. On the other hand, Ibn Hijja al-Hamawi wrote an inscription on the commentary of al-Șafadī under the name of Burūq al-ghayth al-lladhì insajam 'alà sharh Lämiyyat al- 'Ajam. This work, which is separated from other commentaries with the annotations and criticism studies on it, has achieved an independent position in the relevant literature. Among the commentaries on Lamiyyat al- 'Ajam, not only the commentary of al-Safadi formed a separate tradition, but also various studies have been written on Jalal b. Khiḍr (d. after 966/1559) and Abū Jum 'às (d. after 1016/1607) commentaries. This article focuses on the commentaries and annotations literature on $L \bar{a}-$ miyyat al- 'Ajam and various problems of this literature. In this study, the first part of the article, will examine al-Ṭghräî̀s Lämiyyat al- 'Ajam, and the second part, will seek for answers to questions about why comments and hăshiya were written on the ode and what topics were discussed in these works. In addition, in this section, works that are considered important in the relevant literature will be evaluated. In the last section, the identified literature will be categorized, and the manuscript libraries in which they are located and the sources in which they are mentioned will be included. However, before all of this, we will evaluate classical and modern sources that try to determine the literature of Lamiyyat al- 'Ajam or to provide information about this tradition, and point out the main characteristics that separate our work from these.

Keywords: al-Ṭughrāì , Lämiyyat al- 'Ajam, commentary, gloss, the Saljūkiid Empire 


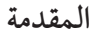

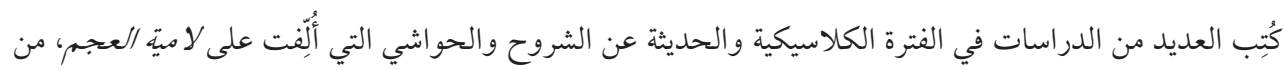

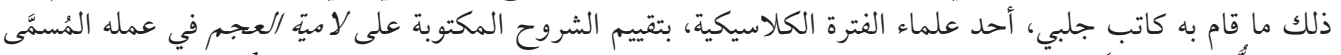

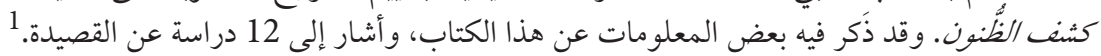

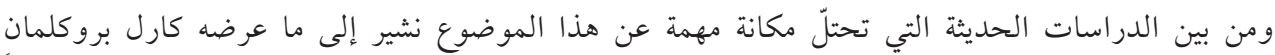
(Carl Brockelmann)

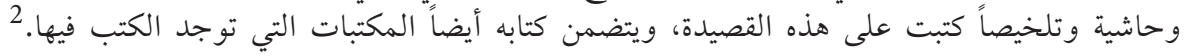

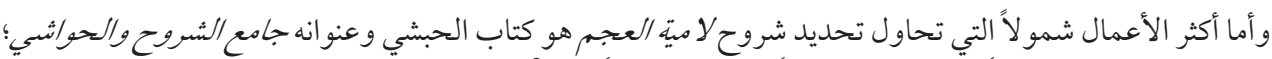

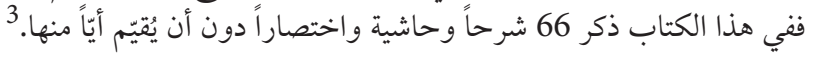

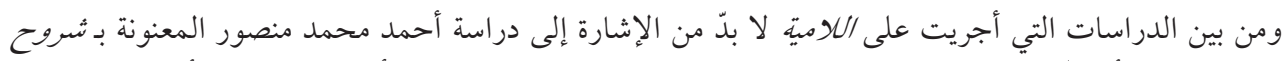

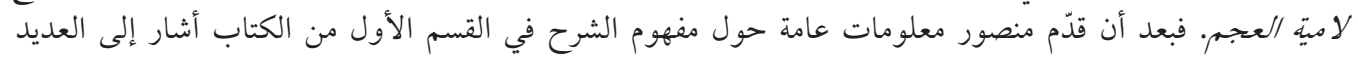

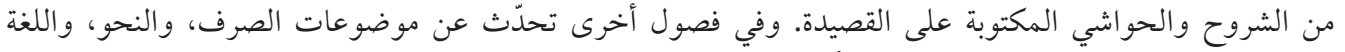

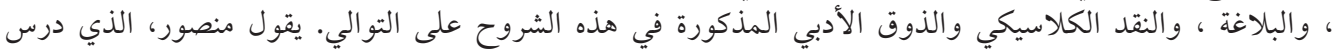

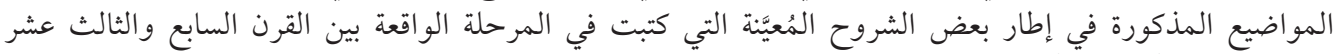

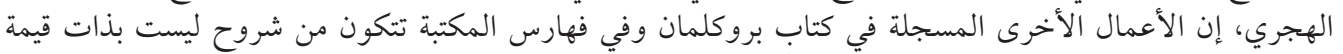

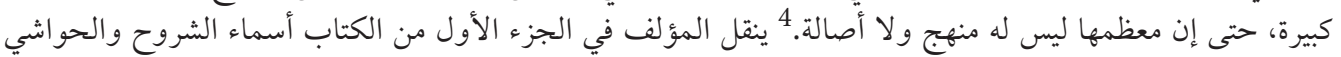

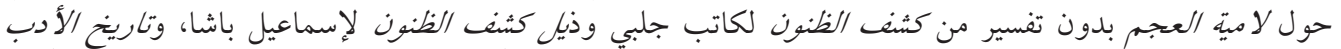
العببي لبروكلمان. كتب الشروح والحواشي.

وذكر علي جواد الطاهر الذي أجرى دراسات مختلفة حول لامية العجمر أنه تمت كتابة أكثر من عشرة شروح على ورتى

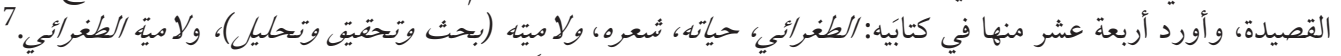

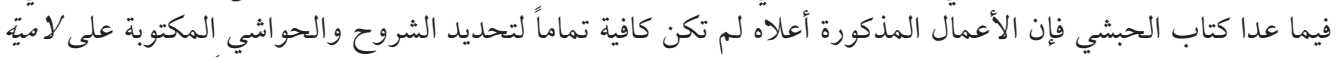

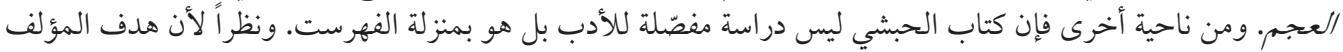

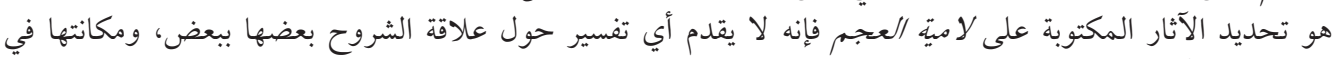
الدراسات الأدبية.

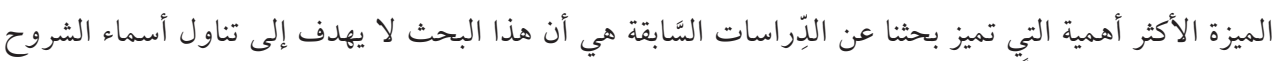

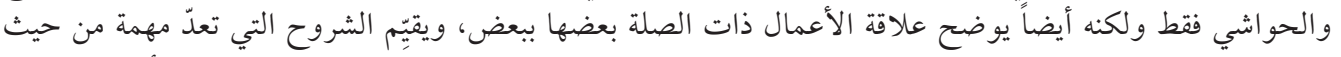

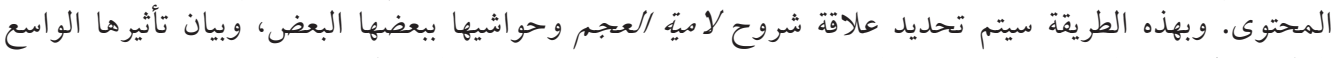

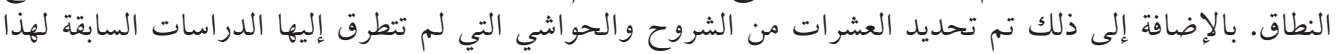




\section{1}

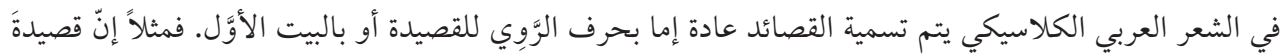

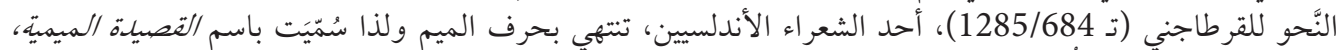

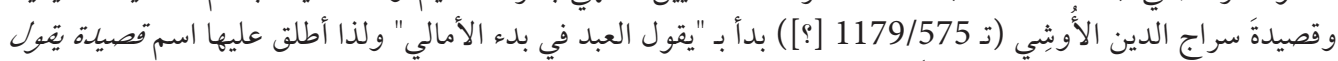

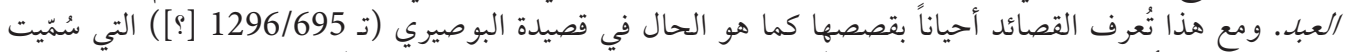

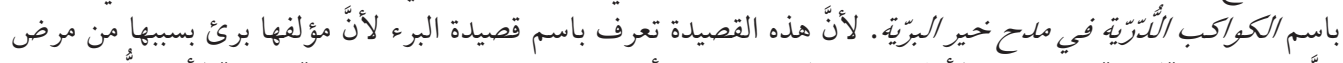

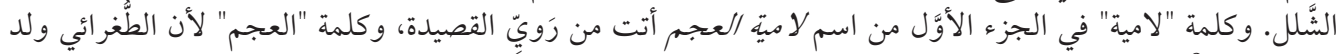
في أصبهان.

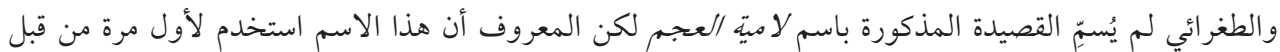

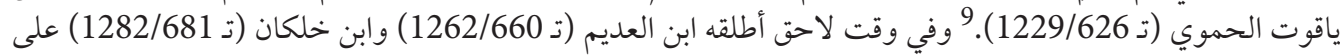

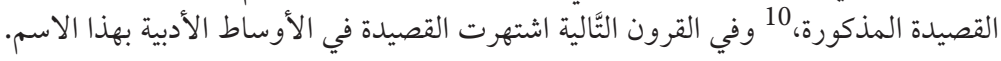

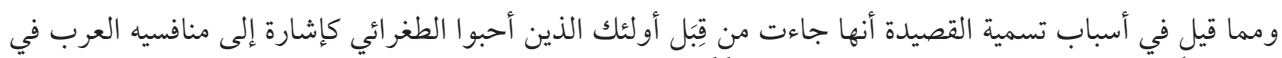

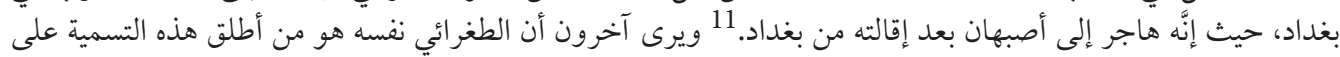

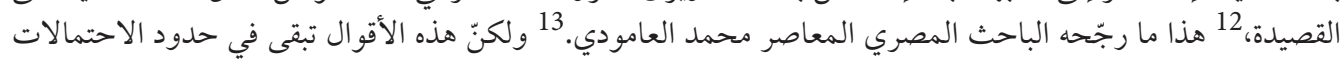
ووجهات النظر التي تفتقد إلى الأدلة الثابتة.

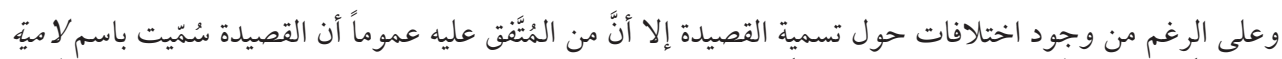

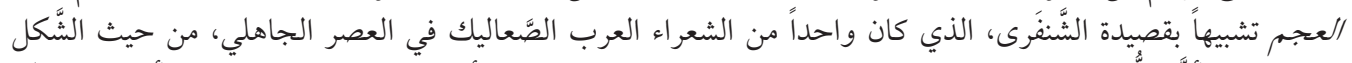

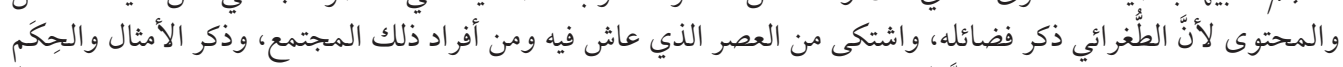

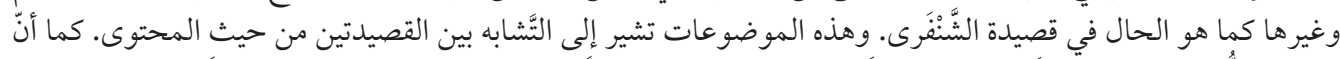

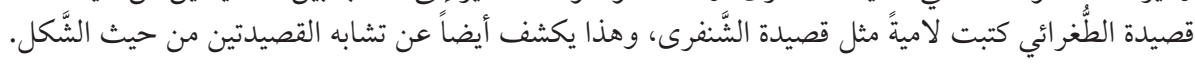

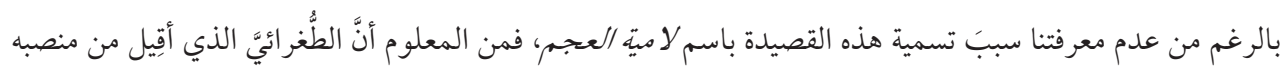

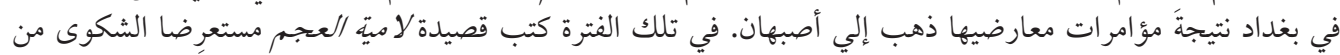

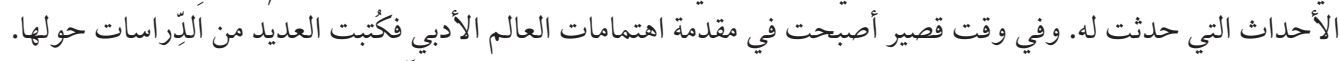

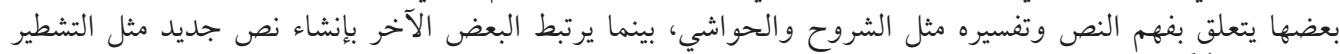
و التخميس. 14

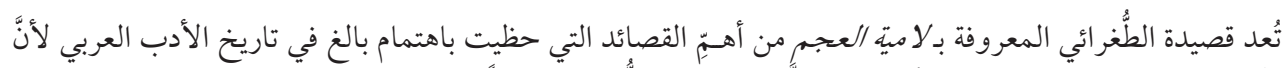

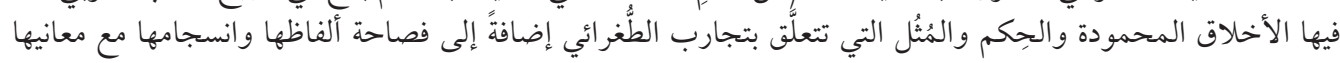

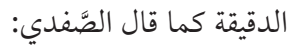

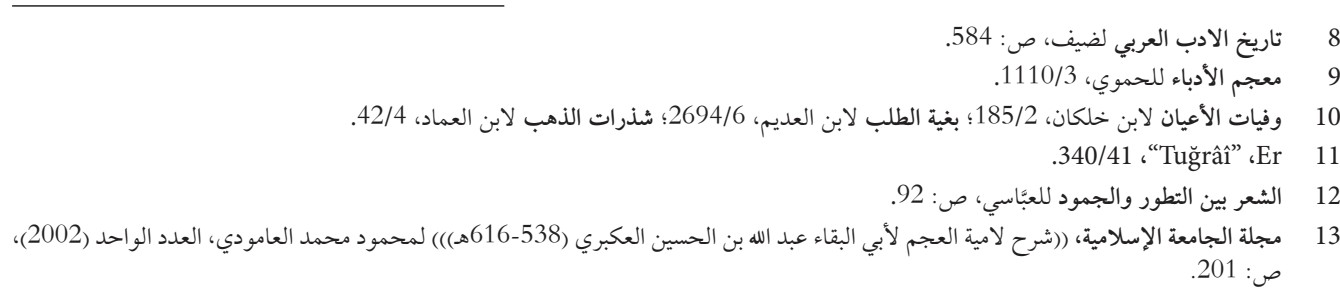

14 
أما فصاحة لفظها فيسبق السَّمعُ إلى حفظها، وأما انسجامها فيطوف منه بخمر الأنس جامها، وأما معانيها فنزهة معانيها،

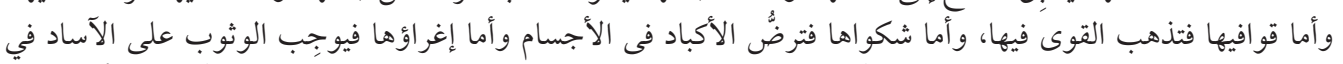

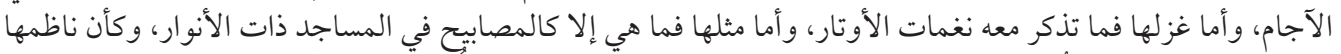

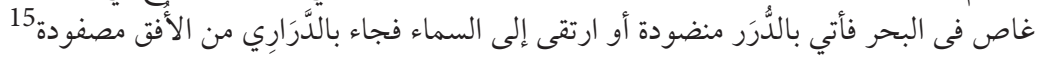

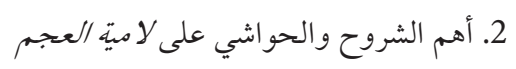

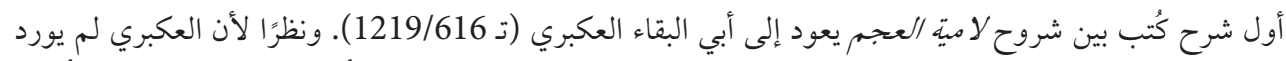

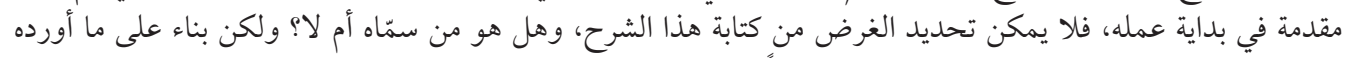

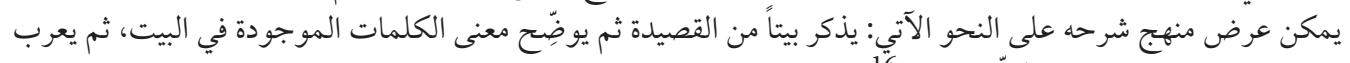

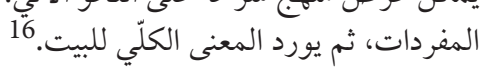

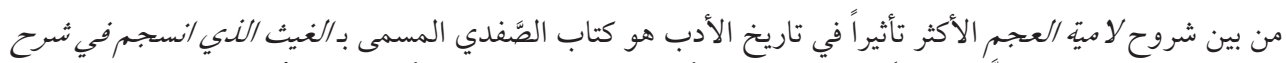

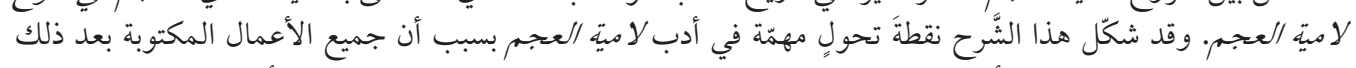

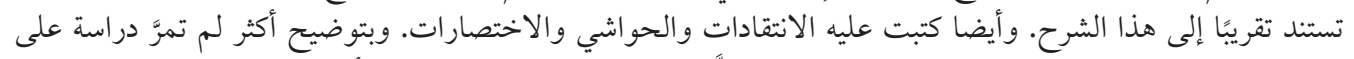

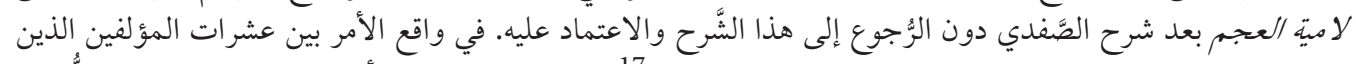

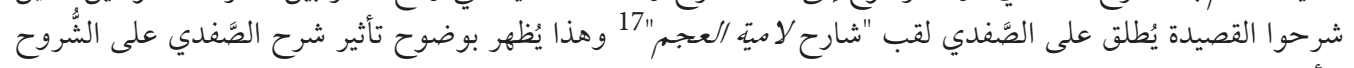
الأخرى.

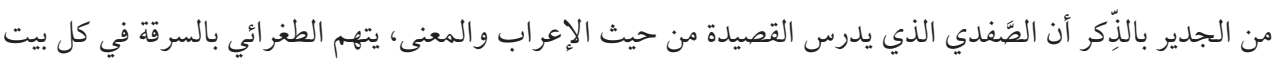

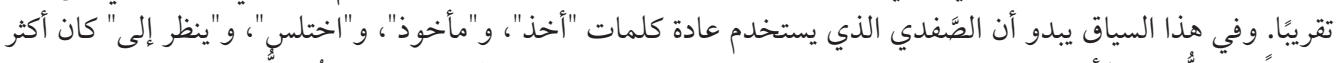

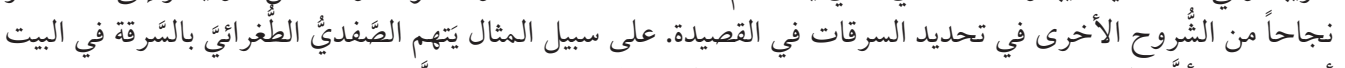

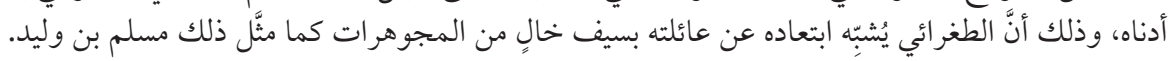

$$
\begin{aligned}
& \text { قال الطغرائي: - مان } \\
& \text { كَالسيفِ عُرِّيَ مْتَنَاه عنِ الخللِ } 18 \\
& \text { وباينتُ حتى صِرتُ للبيَنِن راكباً } \\
& \text { نَاءٍ عَنْ الأهلِ صفر الكَّفِّ منَفِرد }
\end{aligned}
$$

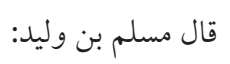

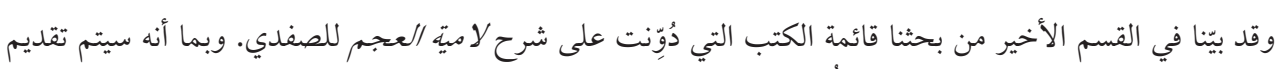

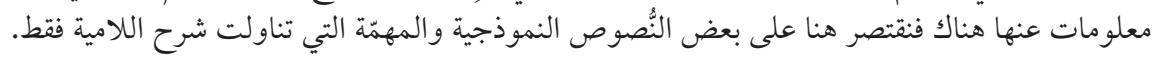
كتب بدر الدين الدماميني دراسة نقدية سماهانزول الغيث الني انسجم على ثرح لامية العجم و انتقد الصَّفديَّ بحدّة.

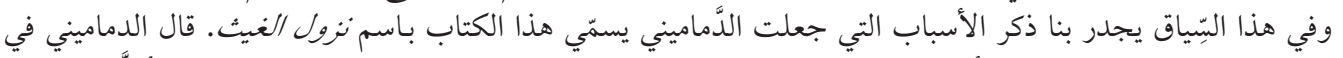

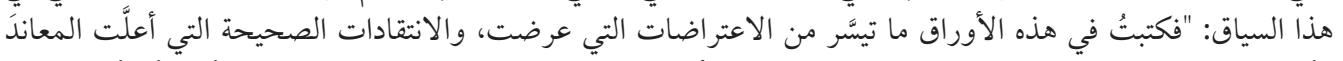

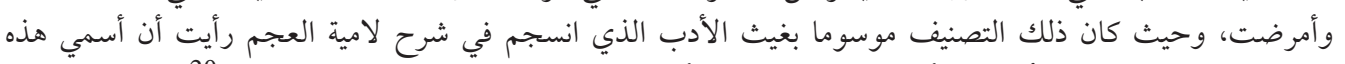

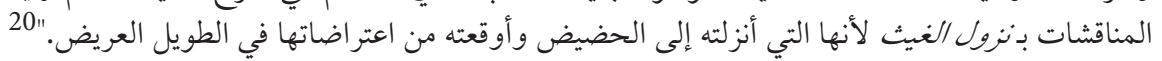

$$
\begin{aligned}
& 15 \\
& 16 \text { مجلة الجامعة الإسلامية، ((شرح لامية العجم لامبة لأبي البقاء العكبري)) لمحمود محمد العامودي، العدد الواحد (2002)، ص: } 204 . \\
& \text { 17 الاستقصاء للناصري، ص:3: } 18 \\
& 18 \\
& 19 \\
& 20
\end{aligned}
$$


كمال الدين الدَّميري اختصر شرح الصَّفدي قائلا بأنَّ الصَّفدي استطرد كثيراً من غير ضرورة. 21 وقد حظي عمل المَل

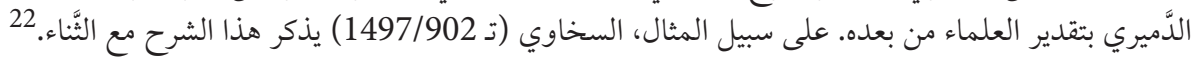

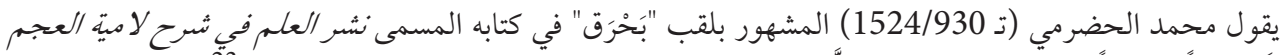

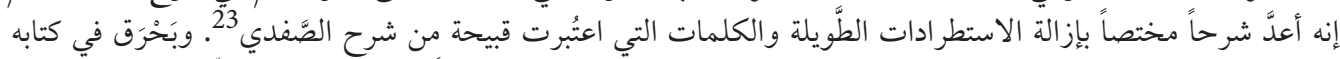

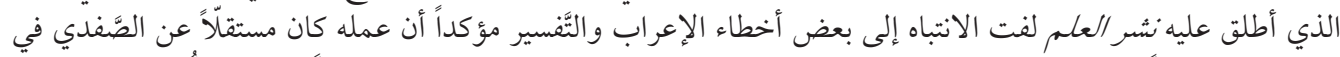

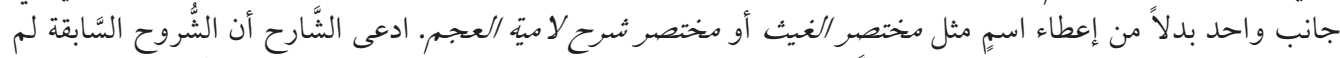

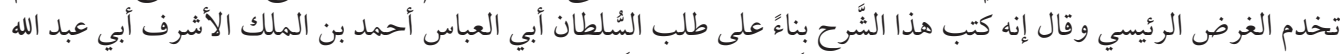

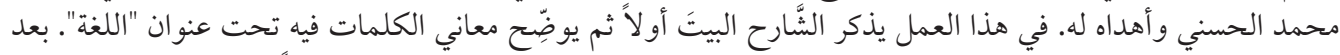

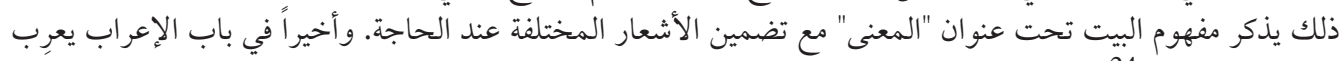

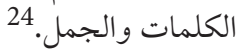

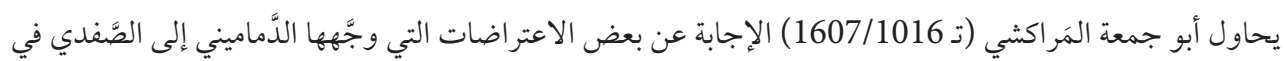

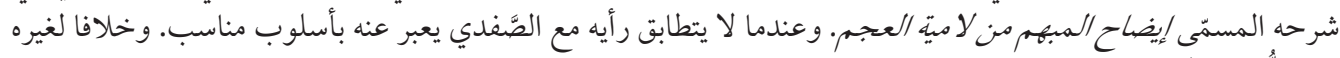

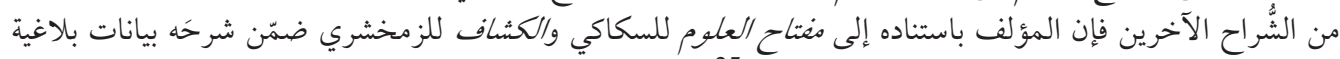
مختلفة. وقد اختصر المكيُّ بن محمد شرحَ المَر اكشي.

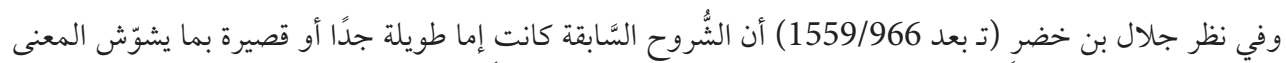

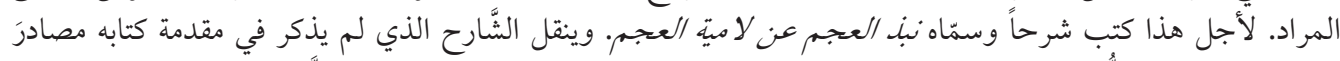

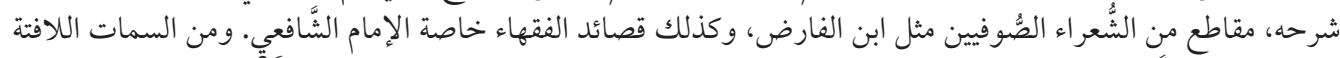

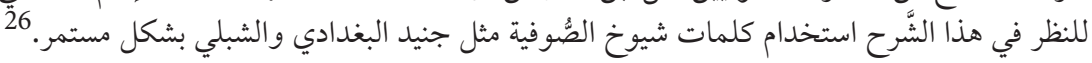

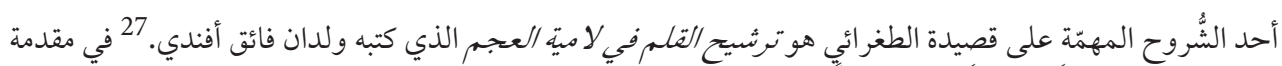

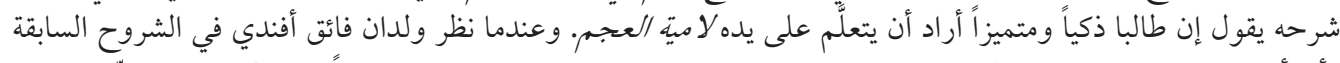

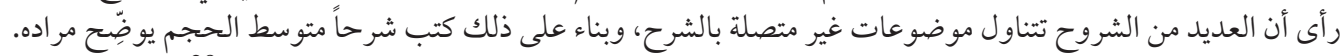

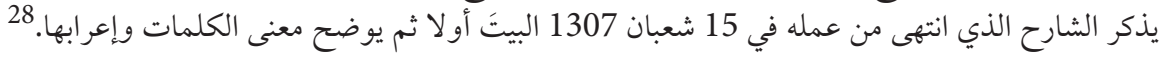
الشرح التركي الوحيد المعروف للامية العجم هو ثرح محمد لبيب أفندي. وقد طبع هذا الشَّرح في طبع خانه عامره عام

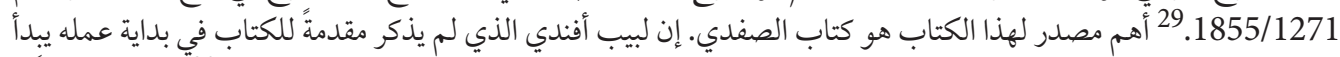

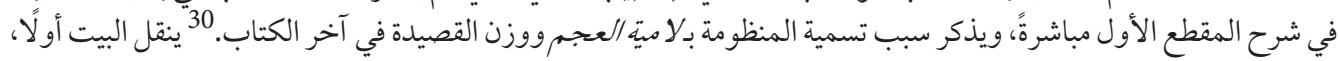

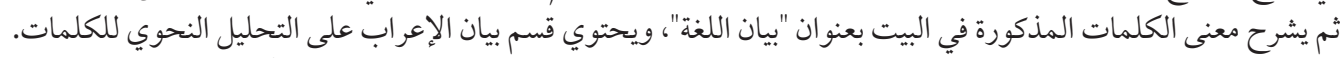

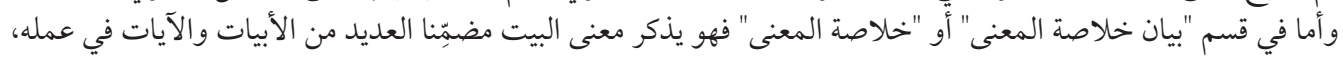

$$
\begin{aligned}
& 21 \text { 2 المقصد الأتم للدميري، ص: 38-39. } \\
& 22 \text { 2 } 23 \\
& 23 \text { نشر العلم للحضرمي، ص: } 22
\end{aligned}
$$

(02.03.2021) http://katalog.ilke.org.tr/detay/612 24

25 مجلة كلية الدعوة الإسلامية، (مختصر شرح لامية العجم لمكي بن محمد)) لعبد الله بن علي السويي، العدد 22 (2005)، ص: 206.

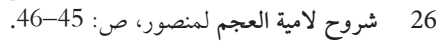

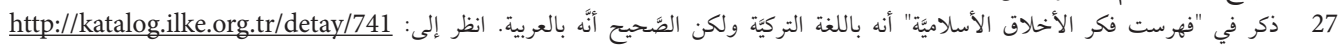

(02.03.2021)

(02.03.2021) http://katalog.ilke.org.tr/detay/741 28

29

30 شرح لامية العجم للبيب أفندي، ص:113. 


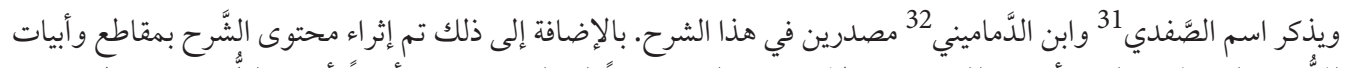

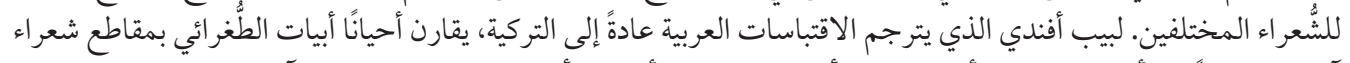

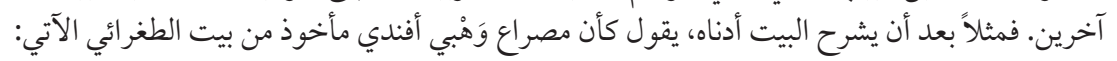

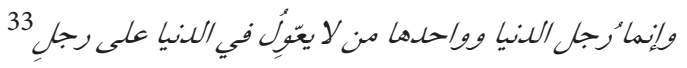

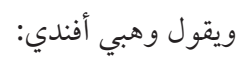

"Dünya adamı ve kâmil-i vâhid olan kişi ancak şol kimsedir ki Dünyada hiç kimseye itimat etmez." 34

$$
\text { 3. شني: رجل الدنيا الوحيد والكامل هو من لا يعتمد على أحد في الدنيا. }
$$

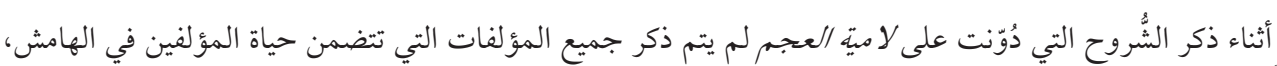

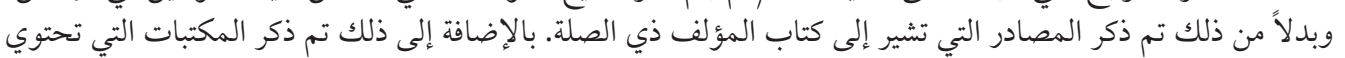
على تلك الشروح:

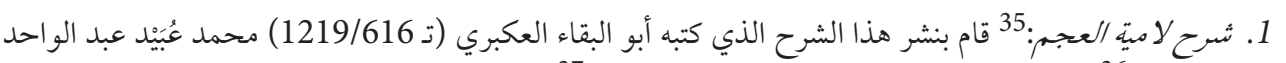

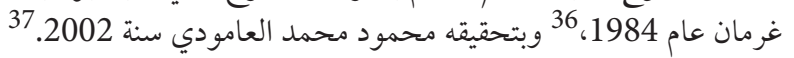

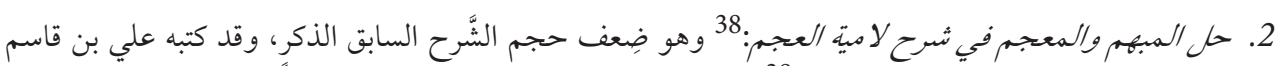

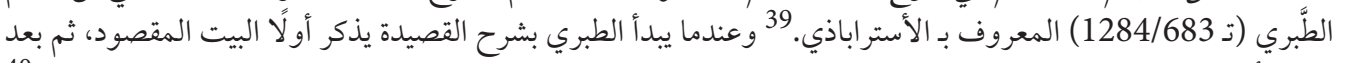

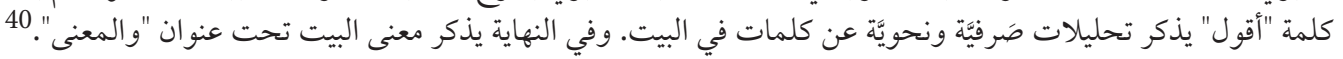

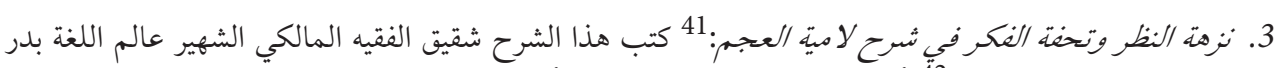

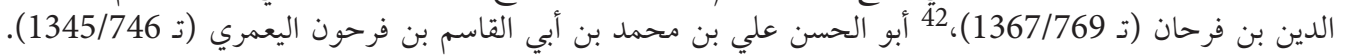

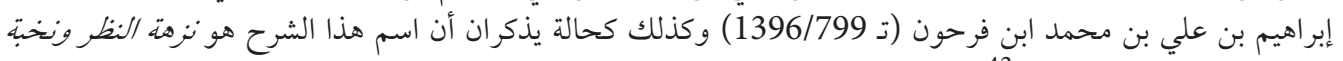
النكر في شرح لامية العجمر. 


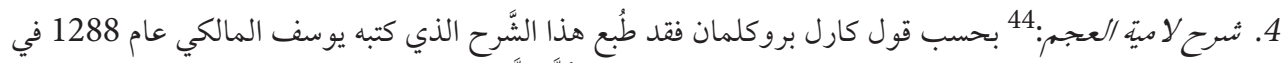

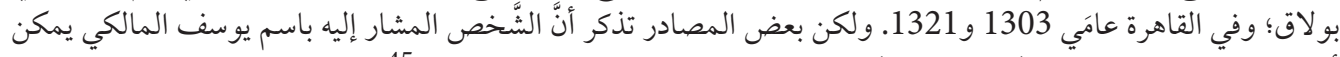
أن يكون هو يونس المالكي (1349/750) مؤلف الكتي الكتاب المسمى الفلك المشحون.

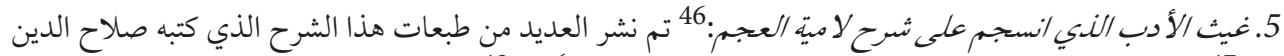

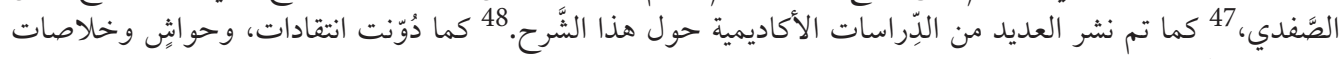

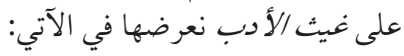

5.1

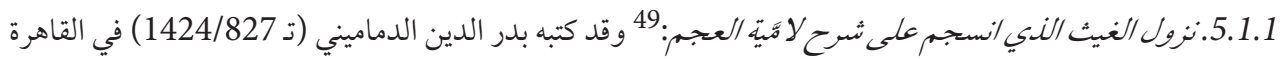

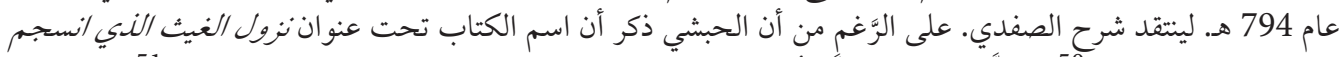

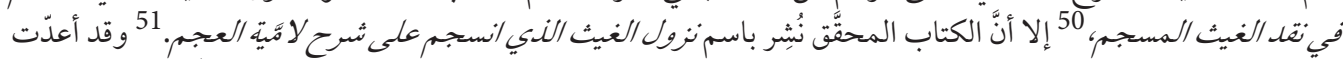

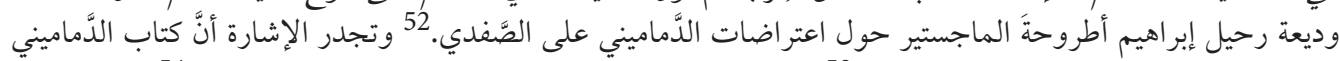

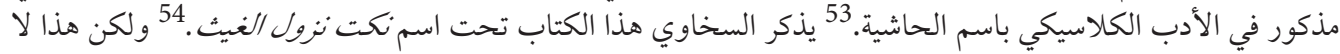

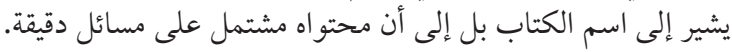

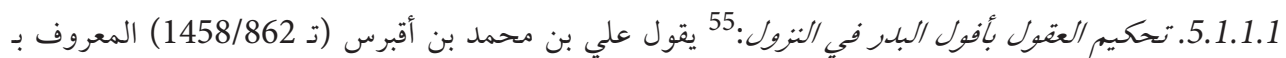

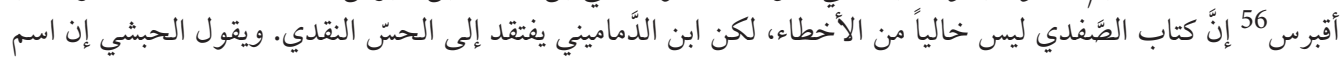

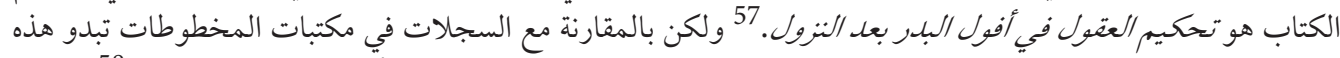

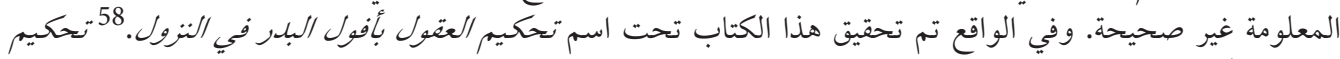

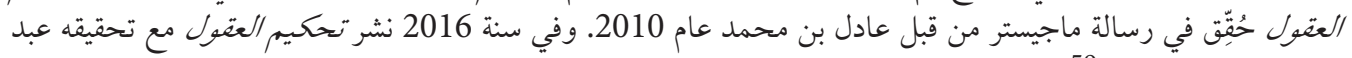

السلام الهمالي سعود.

تاريخ الأدب العربي لبروكلمان، 15/3؛ جامع الشروح للحبشي، 779/3؛ مجلة التربية والعلم، ((وزير الموصل مؤيد الدين الطغرائي: دراسة في سيرته

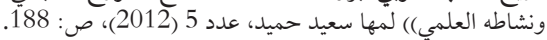
479/3 45

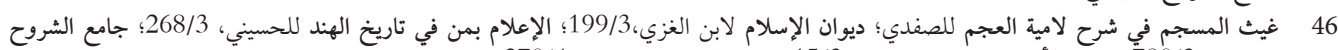

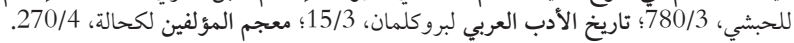
4 47 48 الصفدي وشرحه لرشاد؛ مجلة أهل البيت عليهم السلام، ((الصفدي ومنهجه في شرح لامية الطغرائي)) لأنوار سعيد جواد، العدد 7 (2009)؛ شروح

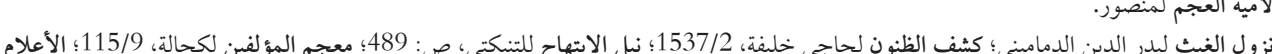

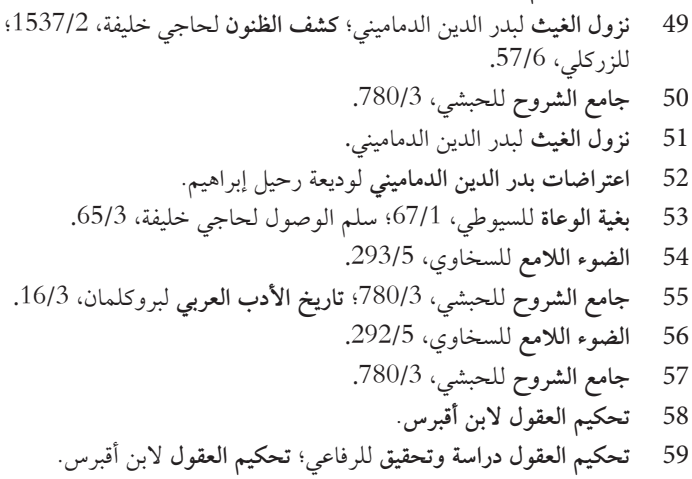


ل1.2.1.2 نضائر الروض بلا ريث عقب نزول الغيث:60 يقول الحبشي إن هذا الكتاب الذي كتبه أحمد بن محمد الحيمي

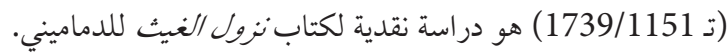

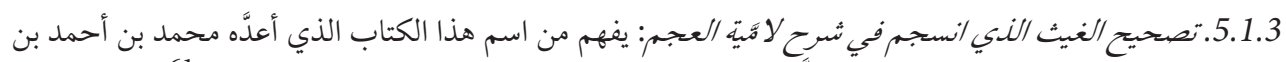

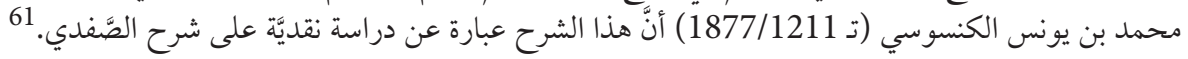

\section{2}

5.2.1. بروق الغيث الني /نسجم على شرح لامية العجم:62 هذا العمل الذي كتبه ابن حجة الحموي (ت 1434/837) فيه نقود كثيرة لكتاب الصَّفدي المذكور أعلاه.

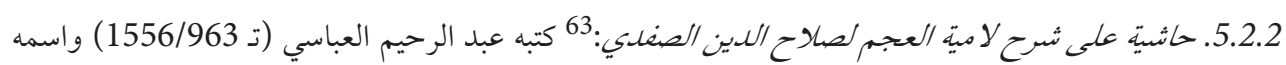
الكامل هو أبو الفتح بدر الدين (زين الدين) عبد الرحيم بن عبد الرح الرحمن الرحن بن أحمد بن الحسن العباسي.

\section{3}

$$
\text { 5.3.1 صلاح الدين الصفدي أعلَّ مختصراً لكتابه. } 64
$$

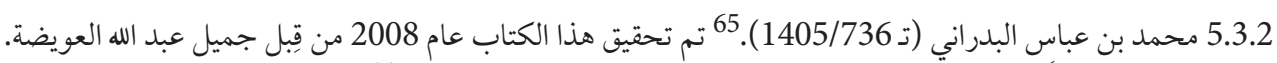

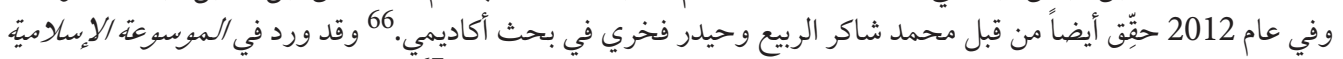

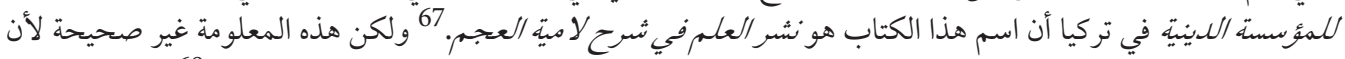

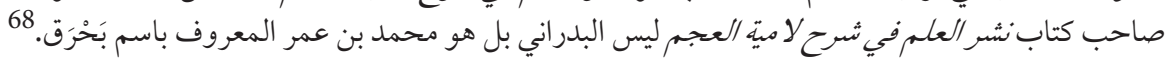

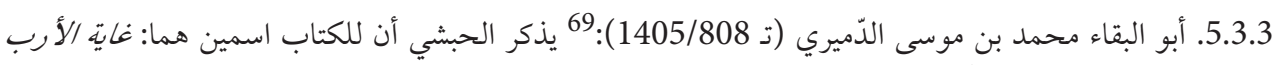

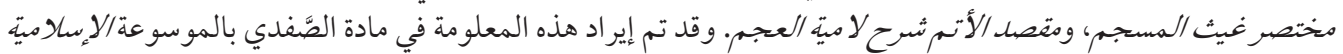

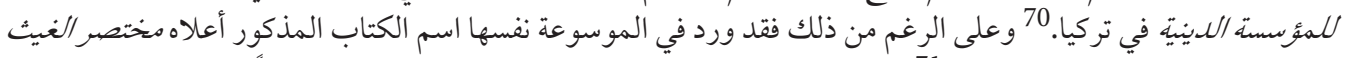

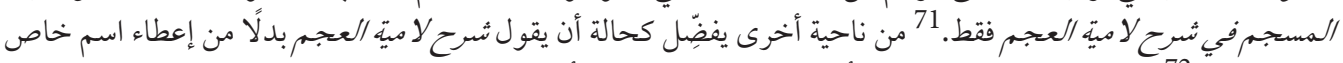
لهذا الكتاب. 72 وقد طبع هذا الكتاب الذي أعده للنشر محمد شادي أرباش في في عام

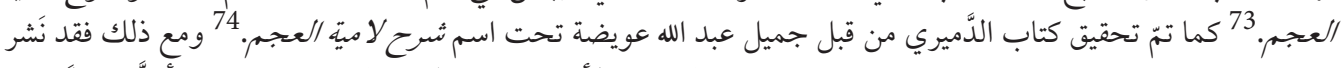

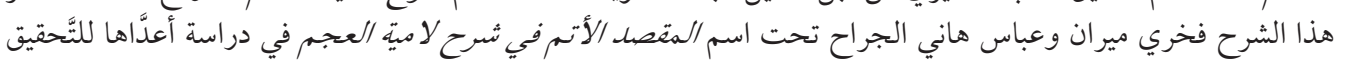

$$
\begin{aligned}
& 60
\end{aligned}
$$

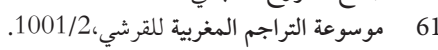

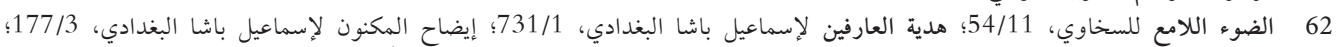

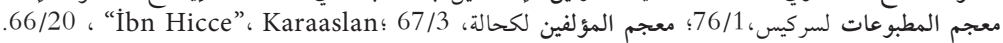

63

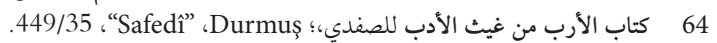

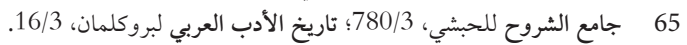

66 فرح البدراني على لامية العجم للبدراني؛ مجلة العلى العلوم الإنسانية، ((شرح البدراني على لاميـة العجـم دراسة وتحقيق)) لمحمد شاكر الربيعي وحيدار فخري ميران، العدد 11، (2012). .449/35، "Safedî"، Durmuş 67 68 69 تاريخ الأدب العربي لبرو كلمان، 16/3؛ جامع الشروح للحبشي، 780/3؛ الأعلام للزركلي، 118/7؛ معجم المؤلفين لكحالة، 65/12. 449/35، "Safedî”، Durmuş 70 .153/9 “Demîrî” ، İzgi 71 66/12 72 73 74 


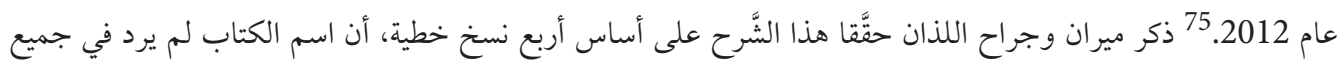

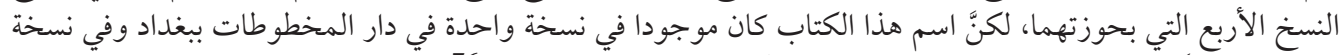

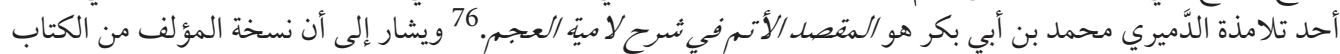
موجودة في مكتبة آيا صوفيا. 77

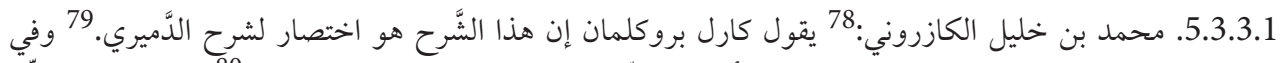

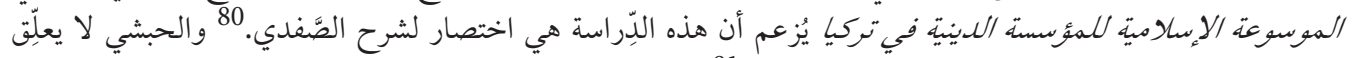

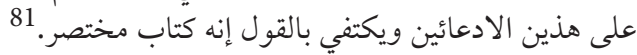

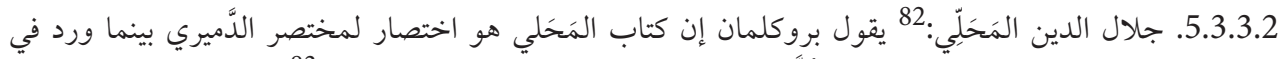

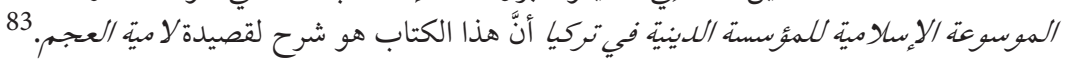

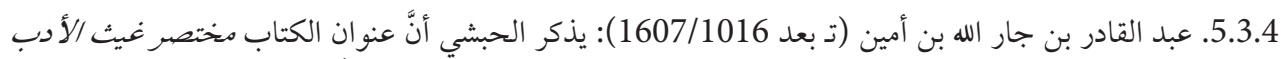

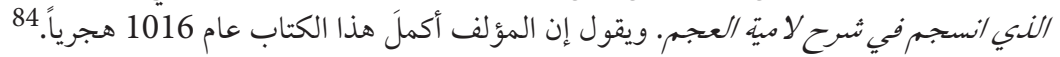

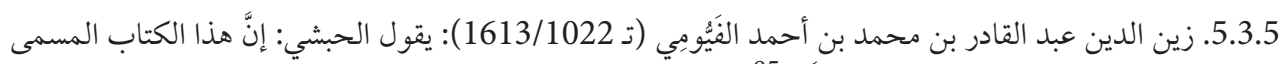

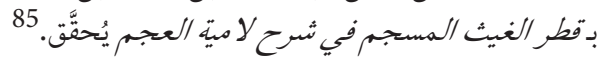

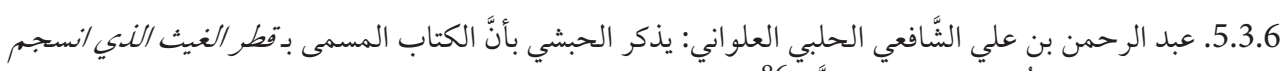

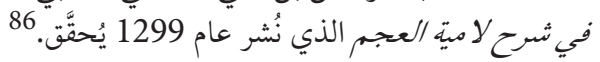
5.3.7. محمد بن أحمد الفاسي (ت 1701/1113): يقول الحبشي: إن اسم الكتاب مختصر شرح الصغلدي على لامية 87 العجr.

5.3.8. جبرائيل بن فرحات مطر الماروني (ت 1140/1727): يُذكر في المصارد أن اسم الكتاب بلوغ الأرب مختصر شرح لامية العجمب. 8.3 .8

5.3.9. محمد بن حسين الكوثري/الكوثراني (ت الت 1815/1230):89 يذكر الحبشي أنَّ اسم الكتاب هو مختصر لامية

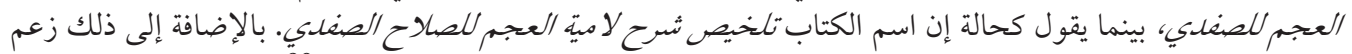
كحالة أن اسم المؤلف هو محمد بن حسن الكوثراني وفرغ من تأليفه في صفر سنة 1230 هـ. 
5.3.10. رضا حسن الكاكوروي: يُذكر أن المجلد الأول من كتاب تنحة الهند وريحانة الزند هو ملخص من شرح صلاح الدين الصفدي. 91.10 5.3.11. عبد الله الأدكاوي (ت بعد 1872/1289): الكتاب المسمى بـ الأرب من غيث الأدب (مختصر الغيث

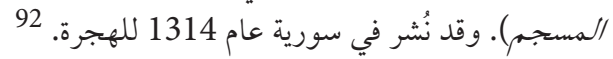

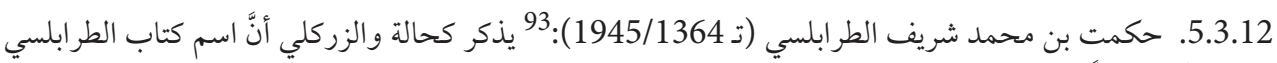

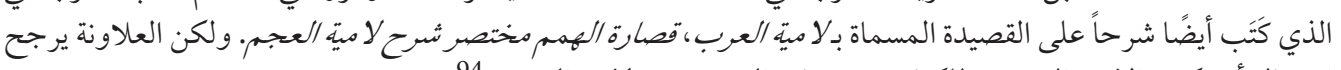

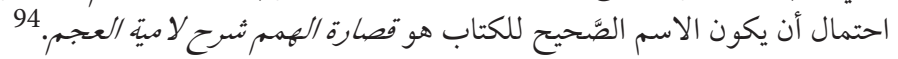
5.3.13. عبده يني باباد: قال كارل بروكلمان إن عبده يني باباد اختصر شرح لامية العجم للصفدي. 95

5.3.14. مؤلِّف مجهول: الكتاب المسمى بـ المتنقى من شرح لامية العجم في مكتبة آيا صوفيا برقم 4115. 96 5.3.15. مؤلف مجهول: يقول كارل بروكلمان إن هذا الكتاب موجود بباريس في رقم 3123، 6044. 97 5.3.16. مؤلف مجهول: هذا الشرح مسجل في مكتبة الفاتح برقم 2/4063. 5.3.17. مؤلف مجهول: يذكر كارل بروكلمان أن هذا الشرح مسجل في مكتبة غوته برقم 2249. 99. 5.3.18. مؤلف مجهول: يذكر كارل برو كلمان أنَّ هذا الكتاب من بين مختصرات شرح الصفدي. 100

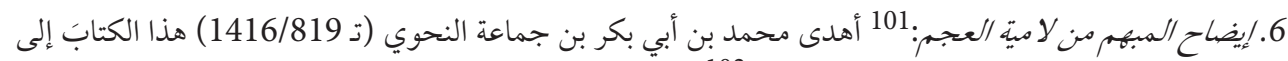

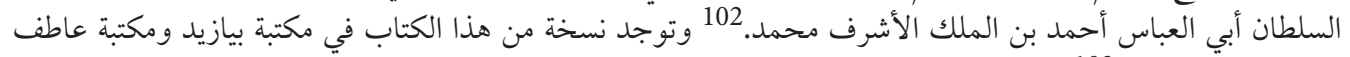
أفندي برقم 02192.

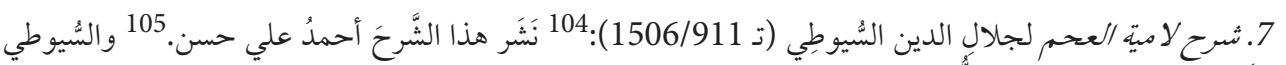

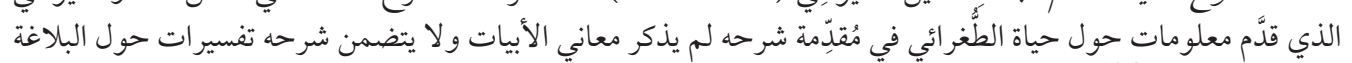

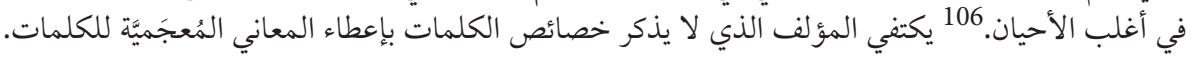

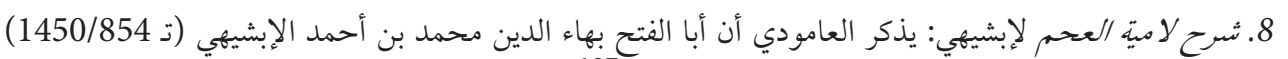

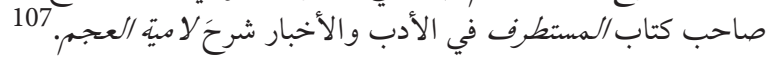

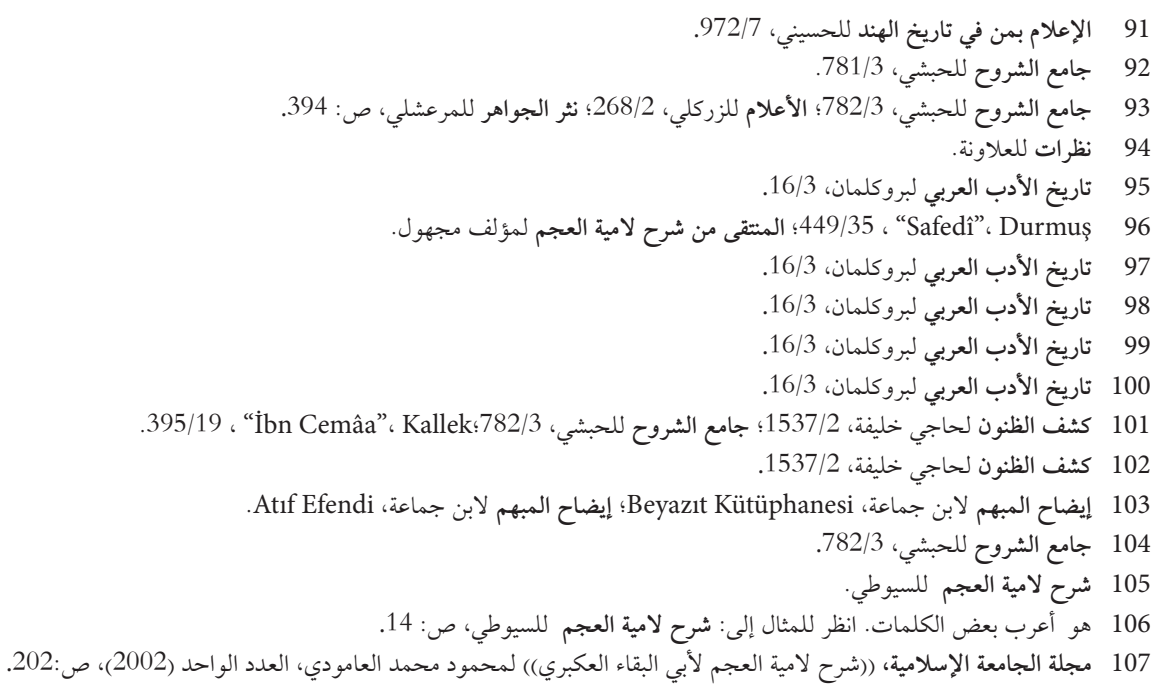


خضر. 108. شرح لامية العجم: قال الحبشي إنَّ شرح زكريا الأنصاري (ت 1520/926) يُحقَّق مع شرح حفيده جلال بن

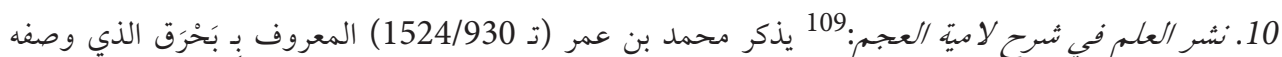

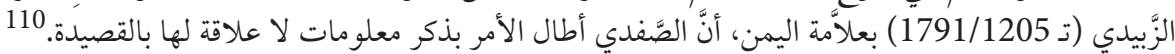

11. نبذ العجم عن لامية العجم:111 بينما قال كاتب جلبي إن جلال بن خضر الحنفي (ت بعد 1559/966) شرح

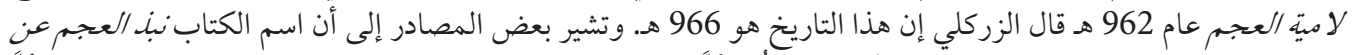

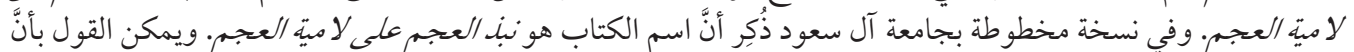

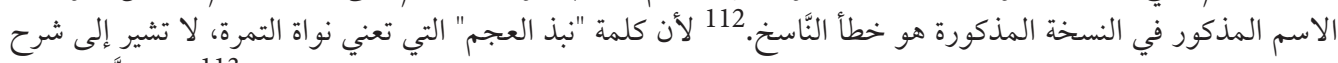

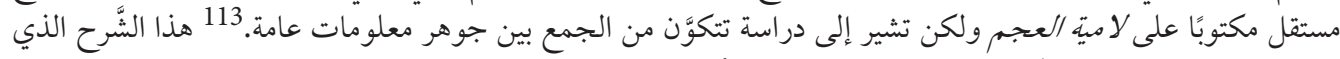

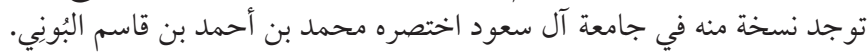

11.1. محمدد بن أحمد بن قاسم البُوني:114 يقول عمر بن دحمان: قد كُتبِ في مقدمة مجموعة أنَّ البوني شرَح الشيخ

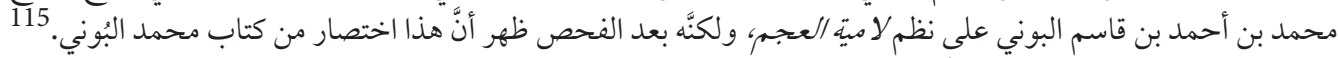

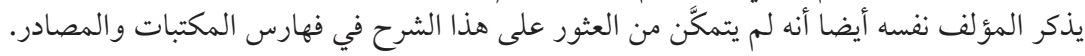

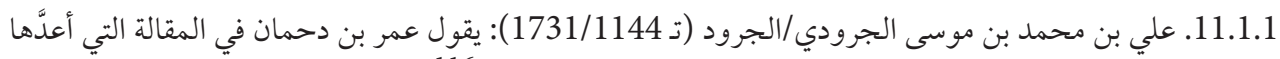

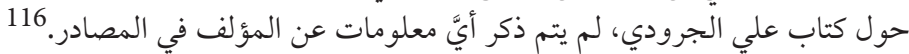

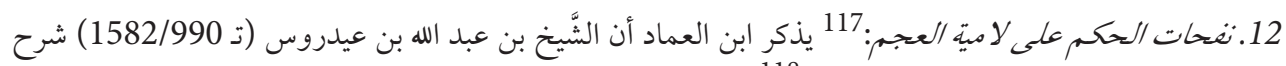

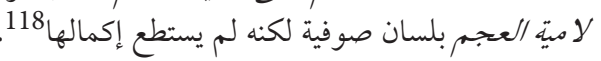
13.ثرح لامية العجم: كتب هذا الشرح القاضي جلال الدين المدني. 119

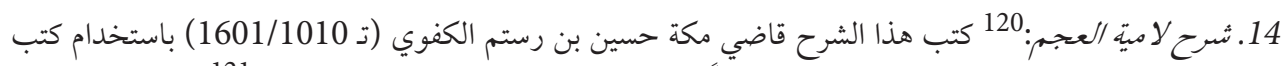

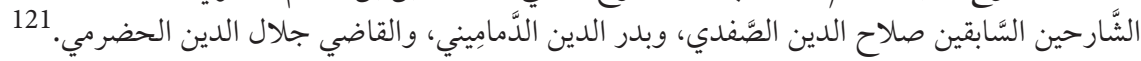

108 ت جامع الشروح للحبشي، 109

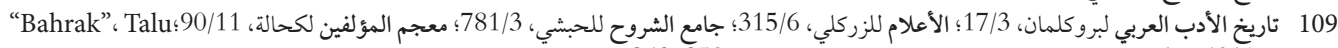
،

(110 110

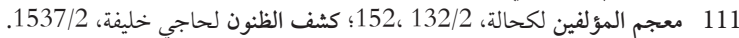

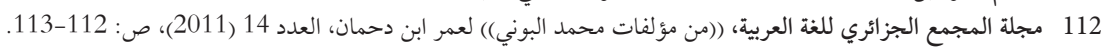

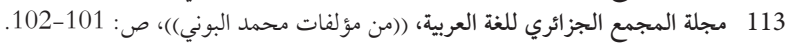
114

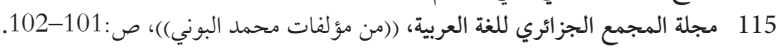

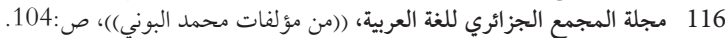
117 هدية العارفين لإسماعيل باشا البغدادي، 420/1 4البرية الإعلام بمن في تاريخ الهند للحسيني، 352/4؛ جامع الشروح للحبشي، 782/3؛ الأعلام للزركلي،

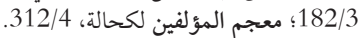

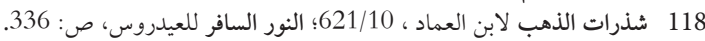

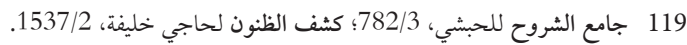
120 كشف الظنون لحاجي خليفة، 1957/2؛ هدية العارفين لإسماعيل باشا البغدادي، 321/1؛؛ معجم المؤلفين لكحالة، 7/4؛ جامع الشروح للحبشي، 187/25 ، "Kefevî Hüseyin Efendi”"، Akpınar:782/3

.187/25 ، "Kefevî Hüseyin Efendi”، Akpınar 121 


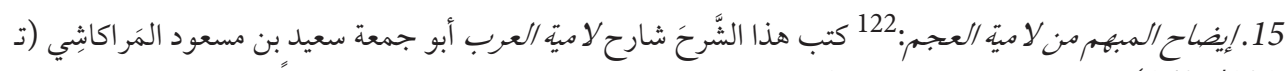

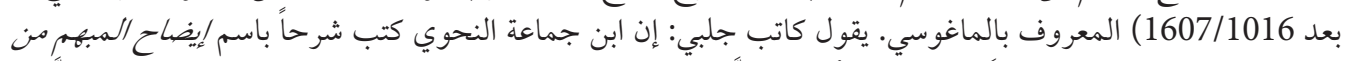

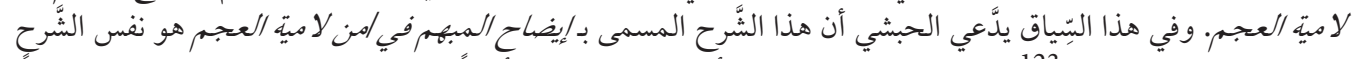

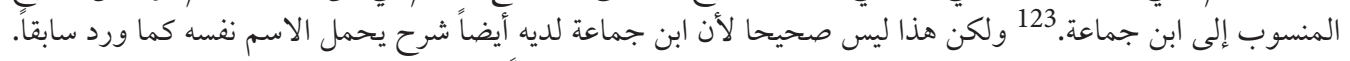

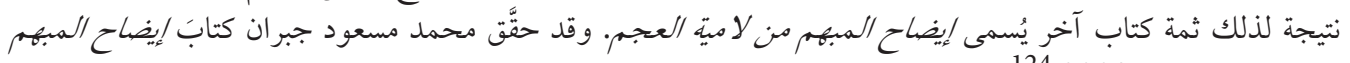
للماغوسي في عام 2009. 124

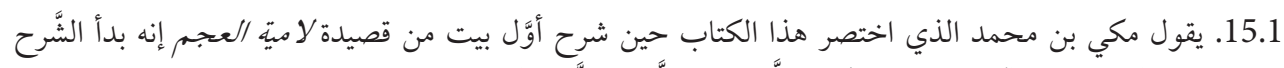

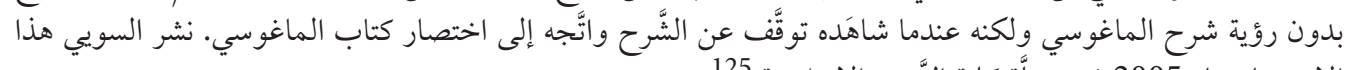
الاختصارَ عام 2005 في مجلَّة كليَّة الدَّعوة الإسلاميَّة. 125

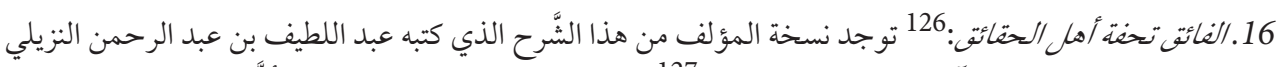

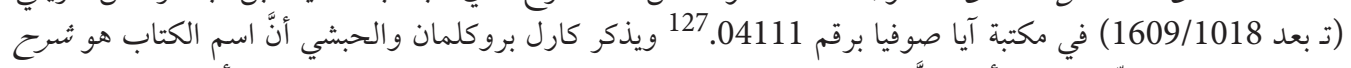

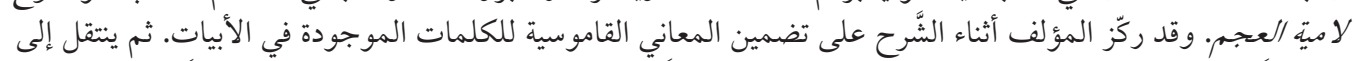

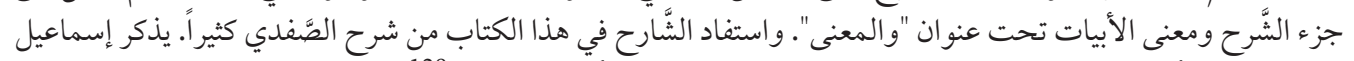

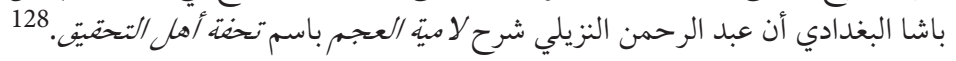

17. تحرير العلم شرح لامية العجم: كتب هذا الشَّرح محمد بن عبد المطيع الطبري (ت 1622/1032). 129

18. ثرح لامية العجم: كتب هذا الشَّرح الحسن بن شمس الدين جحاف (ت 1055هـ). يذكر الحبشي كتاريخ وفاة

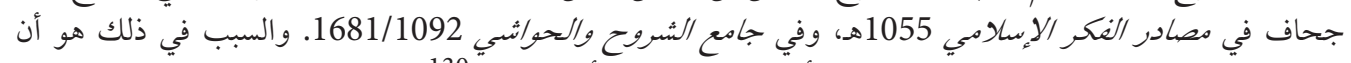

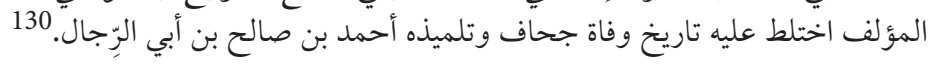

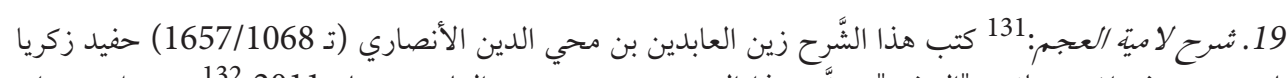

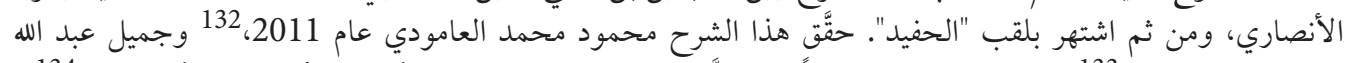

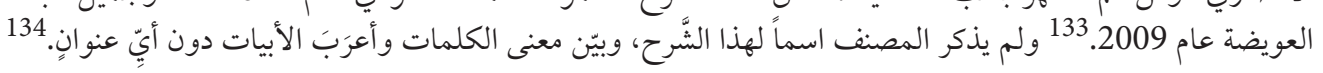

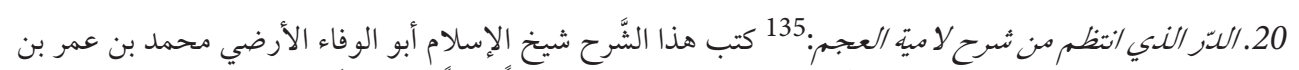

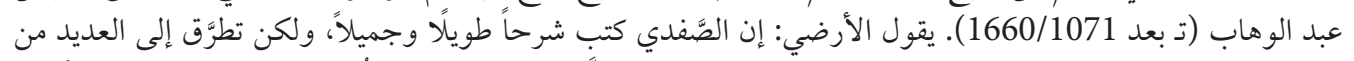

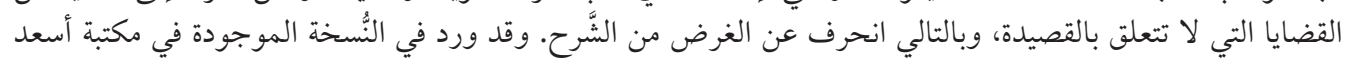

122 جامع الشروح للحبشي، 783/3؛ الأعلام للزركلي، 183/3 / 1023؛ معجم المؤلفين لكحالة، 232/4.

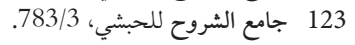

124 125 مجلة كلية الدعوة الإسلامية، ((مختصر شرح لامية العجم لمكي بن محمد)) لعبد الله بن علي السويي، العدد 22 (2005)، ص: 206.

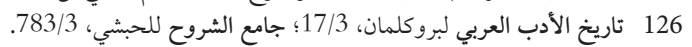
127 128 إيضاح المكنون لإسماعيل باشا البغدادي، 129

129 جامع الشروح للحبشي، 783/3.

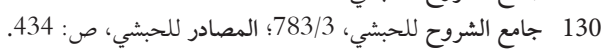
131 تاريخ الأدب العربي لبروكلمان، 18/3؛ معجم المؤلفين لكحالة، 198/4؛ الدئ جامع الشروح للحبشي، 783/3. 132 133

134

135 جامع الشروح للحبشي، 783/3. 
أفندي أن الناسخ قد أكملَ نسخ الكتاب عام 1071. في هذا الشَّرح الذي يركز فيه المؤلف على معنى الكلمات تم تضمين

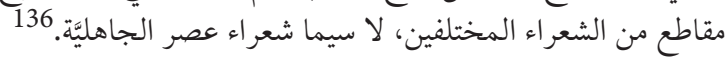

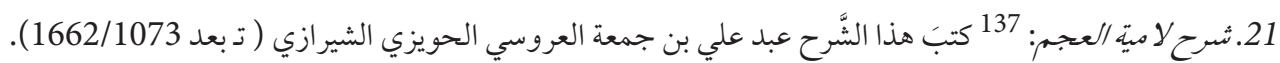

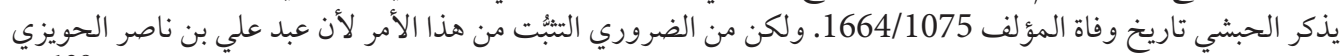

الذي يختلط مع المؤلف توفي في هذا التاريخ. المؤلف عبد علي من من مذهنب الإمامية وله تفسير يسمى نور الثقلين. 138

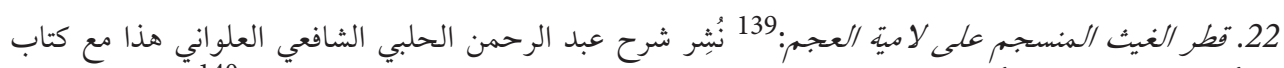

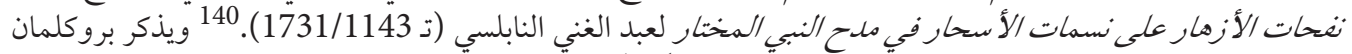

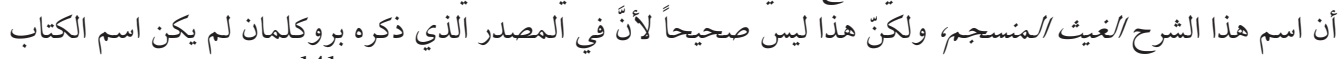

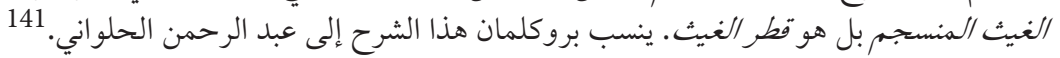

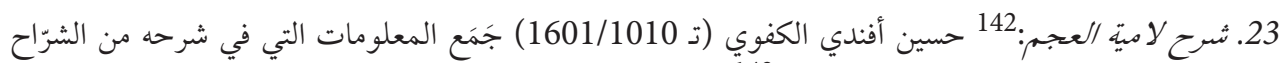

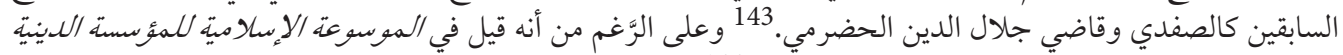

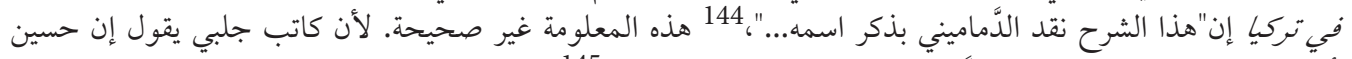

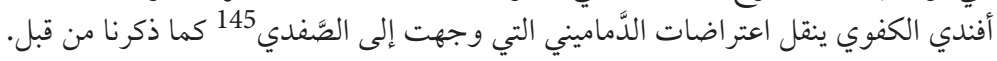
24. شرح لامية العجم:146 ينسب برو كلمان هذا الشَّرح إلى أيوب بن موسى الكفوي.

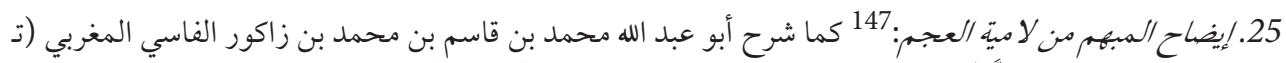

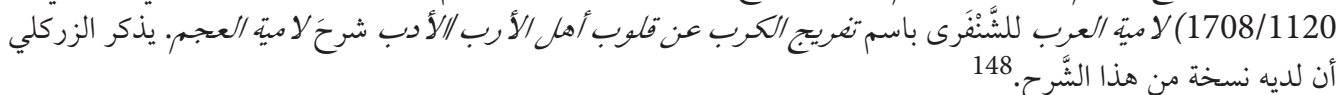

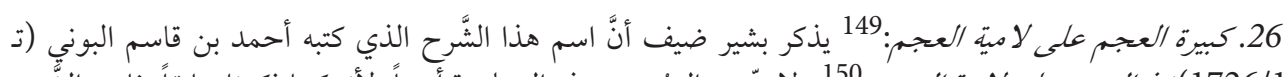

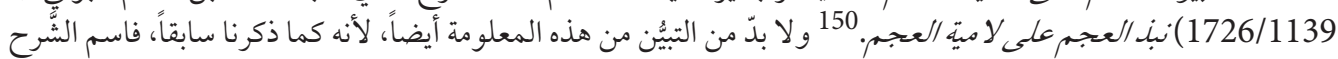

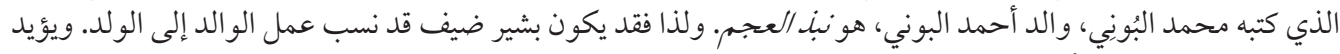

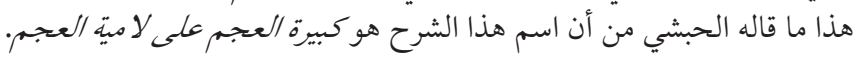

$$
\begin{aligned}
& 136 \text { الدر الذي انتظم لأبي الوفاء الأرضي. }
\end{aligned}
$$

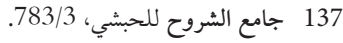

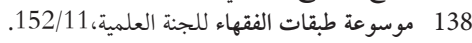

$$
\begin{aligned}
& 139 \text { ت تاريخ الأدب العربي لبروكلمان، 18/3. } \\
& 140 \\
& 141 \text { ت تاريخ الأدب العربي لبروكلمان، 17/3. }
\end{aligned}
$$

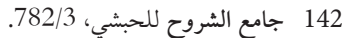

.187/25 ، "Kefevî Hüseyin Efendi”، Akpınar 144

145 كشف الظنون لحاجي خليفة، 14637/2 146 146 تاريخ الأدب العربي لبرو كلمان، 18/3؛ 183/3، جامع الشروح للحبشي، 783/3.

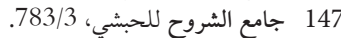
148 الأعلام للزركلي، 148

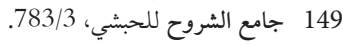




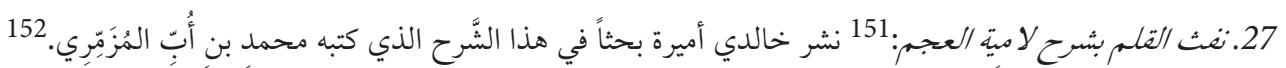

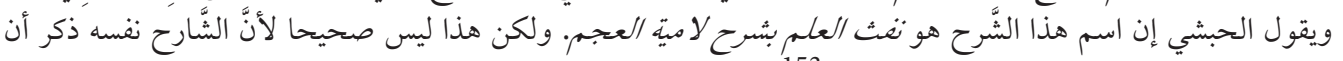

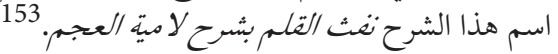

28. شرح لامية العجم:154 كتب هذا الشرح علي بن علي زيد التونسي المعروف بالزرلي (ت 1758/1171).

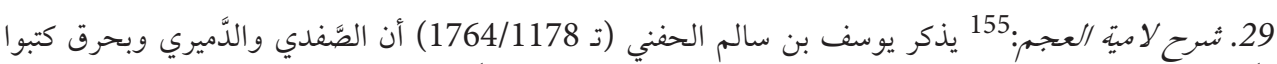

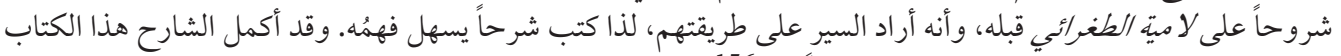

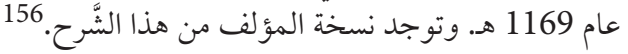

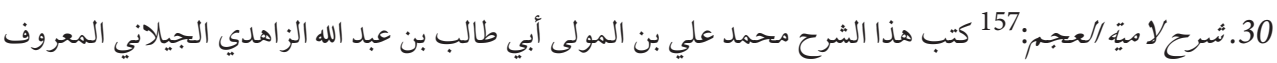
بالشيخ علي خازن (ت 1707/1119). 31. عقل الأمثال والحكمم بجيد لامية العجم: 158 كتبه عطاء الله بن أحمد بن عطاء الله الأزهري المعروف باسم عطاء

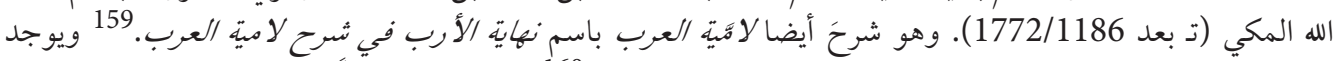

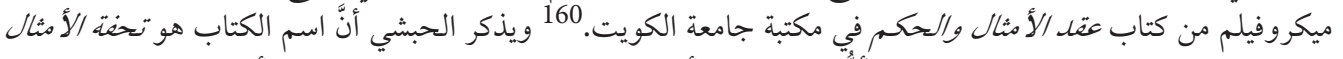

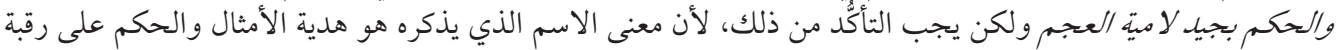

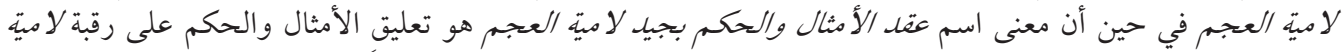

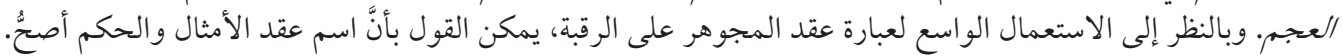

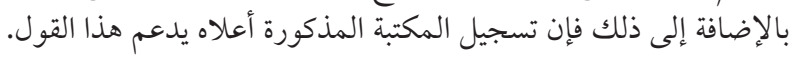

32. ثرح لامية العجم:161 يقول الحبشي إنَّ شرحَ محمد بن محمد العدوي في مكتبة نور عثمانية برقم 04032. 33. إزالة الوجم على لامية العجمر:162 كتَب هذا الشرح محمد بن أحمد بن عبد القادر المعسكري الرَّاشدي الجزائري

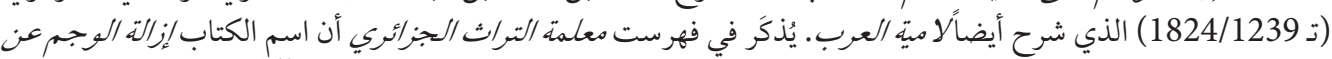

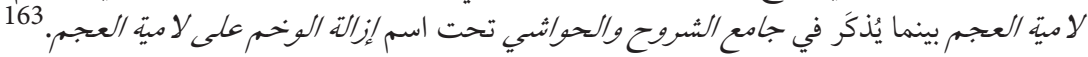

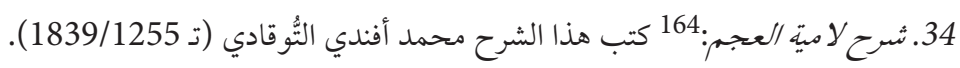

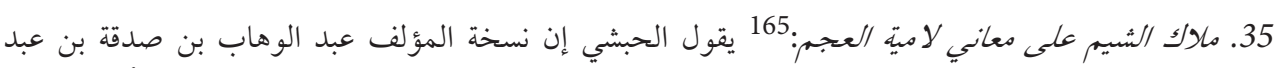

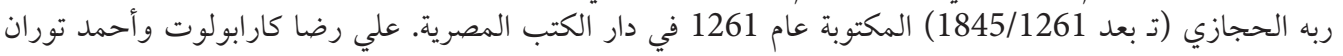

$$
\begin{aligned}
& 151 \\
& 152 \text { مجلة رفوف ((منهج ابن أب المزمري)) لأميرة خالدي، العدد العد } 2 \text { (2017) (2017) }
\end{aligned}
$$

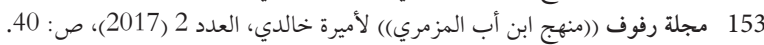

$$
\begin{aligned}
& 154 \\
& 155 \text { جامع الشروح للحبشي، } 156
\end{aligned}
$$

https://ketabpedia.com/\%D8\%AA\%D8\%AD\%D9\%85\%D9\%8A\%D9\%84/\%D8\%B4\%D8\%B1\%D8\%AD- 156 \%D9\%84\%D8\%A7\%D9\%85\%D9\%8A\%D8\%A9-\%D8\%A7\%D9\%84\%D8\%B9\%D8\%AC\%D9\%85-5/ (02.03.2021)

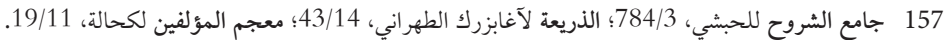

$$
\begin{aligned}
& 158 \text { جامع الشروح للحبشي، } 159
\end{aligned}
$$

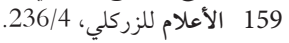

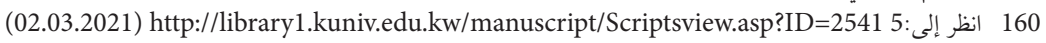
161 162 جامع الشروح للحبشي، 163

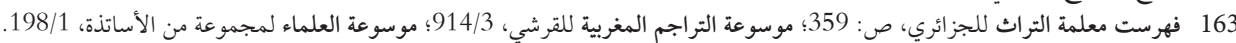
164 جامع الشروح للحبشي، 163 165 جامع الشروح للحبشي، 784/3. 


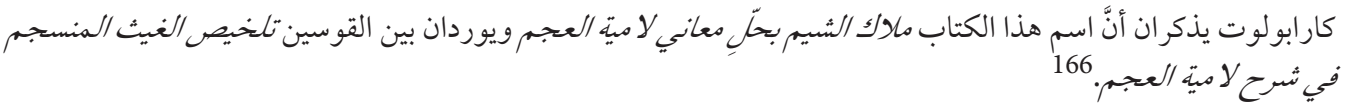

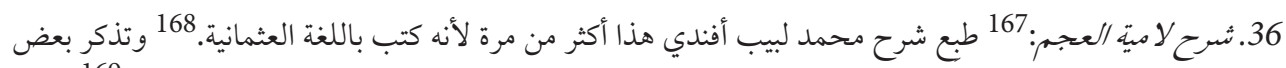

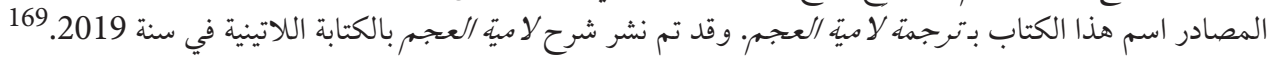

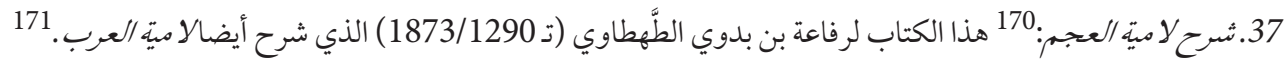

$$
\begin{aligned}
& \text { 38. شرح لامية العجم:172 يقول الحبشي إنَّ كاتبه هو يوسف بن فارس شلتون (ت 1896/1314 ) طبع بلبنان. }
\end{aligned}
$$

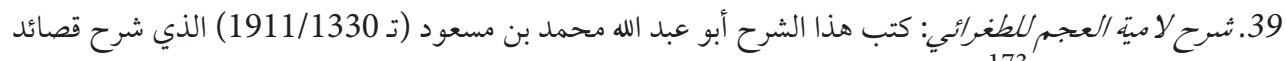

$$
\begin{aligned}
& \text { بانت سعاد والهمنية والبردة. } 173 \\
& \text { 40. فتح المعجم من لامية العجم:174 طبع شرح محمد بن مصطفى بوجندار (ت 1926/1345) هذا في فاس. } 175
\end{aligned}
$$

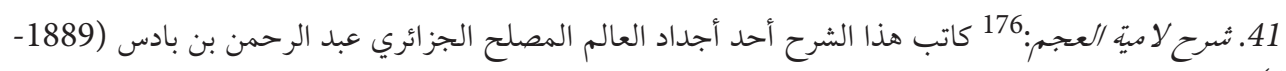

$$
\begin{aligned}
& \text { 1940)، بركات بن البادس الجزائري. لومئ. }
\end{aligned}
$$

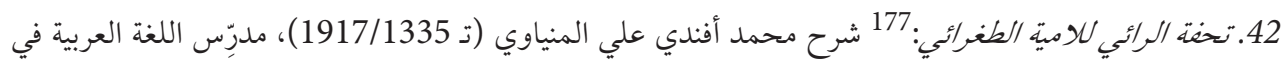

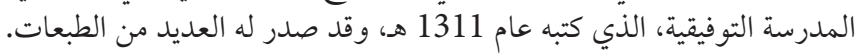

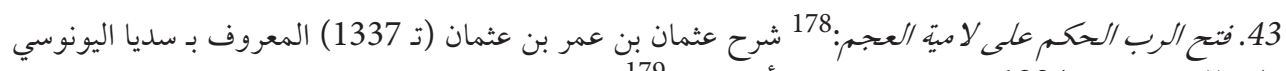

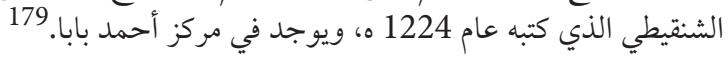

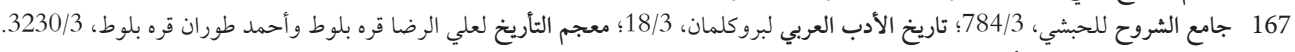
168

Lebib Efendi J Değişmedi Gecenin Rengi 169

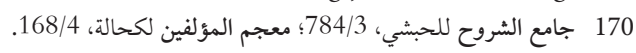
97/35 “Rifâa et-Tahtâvî” ، Hilal 171 172 جامع الشروح للحبشي، 173 173 سوس العالمة للسوسي، ص: 174 174 175 امع الشروح للحبشي، 178/3.

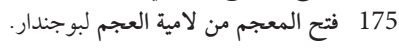

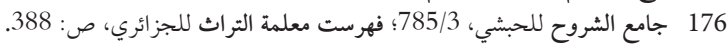

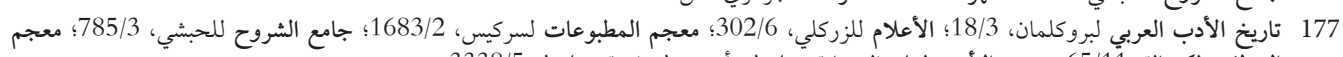

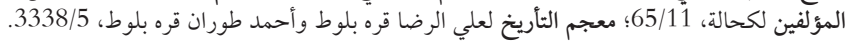

178 جامع الشروح للحبشي، 179 http://www.almajidcenter.org/material_details.php?bId=722353\&encQry=U0VMRUNUIGJvb2tzLmlkLCBib29rc- 179 y50aXRsZSwgIGJvb2tzLmxhdGluX25hbWUsIG1hbnVzY3JpcHRfc3ViamVjdC50aXRsZV9lbiBhcyBzdWJqZWN0VGl0bGVFbixtYW51c2NyaXB0X3N1YmplY3QudGl0bGVfYXJfZmlsdGVyLCBtYW51c2NyaXB0X3N1YmplY3QudGl0bGVfYXIgYXMgc3ViamVjdFRpdGxlQXIsIGJvb2tzLnN0YXRlbWVudF9vZ19yZXNwb25zZSwgYm9va3MuZW5fbmFtZSBGUk9NIGJvb2tzIElOTkVSIEpPSU4gbWFudXNjcmlwdF93aXRoX3N1YmplY3QgT04gbWFudXNjcmlwdF93aXRoX3N1YmplY3QuYm9va19pZCA9IGJvb2tzLmlkIElOTkVSIEpPSU4gbWFudXNjcmlwdF9zdWJqZWN0IE9OIG1hbnVzY3JpcHRfc3ViamVjdC5pZCA9IG1hbnVzY3JpcHRfd210aF9zdWJqZWN0LnN1YmplY3RfaWQgV0hFUkUgICggbWFudXNjcmlwdF9zdWJqZWN0LnRpdGxlX2VuICA9ICfYp9mE2KPYr9ioJyAgT1IgIG1hbnVzY3JpcHRfc3ViamVjdC50aXRsZV9hciAgPSAn2KfZhNij2K/ YqCcgIE9SICBtYW51c2NyaXB0X3N1YmplY3QudGl0bGVfYXJfZmlsdGVyICA9ICfYp9mE2KPYr9ioJyApICAgQU5EIGJvb2tzLmVuX25hbWUgPSAnTWFudXNjcmlwdCcgIEdST1VQIEJZIGJvb2tzLmlk\&current=4357\&to- 


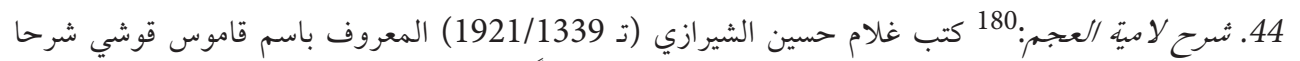

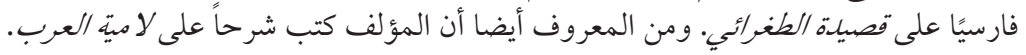

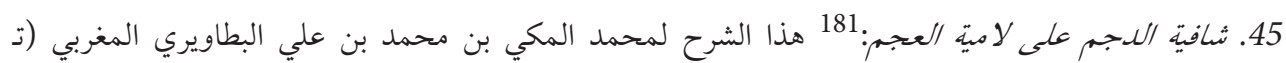

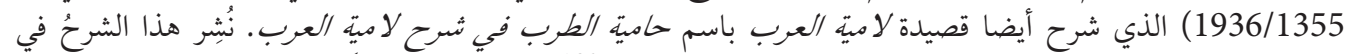

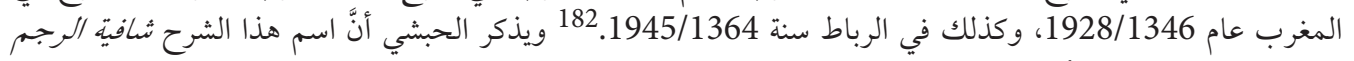

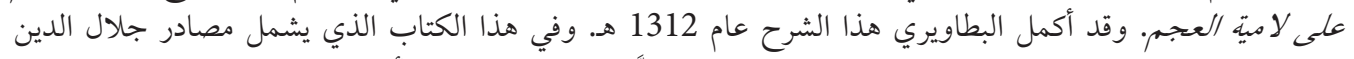

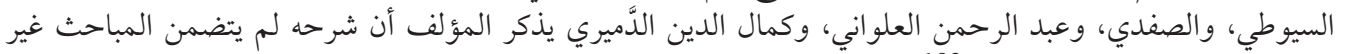
اللائقة المذكورة في شروح أخرى 183.

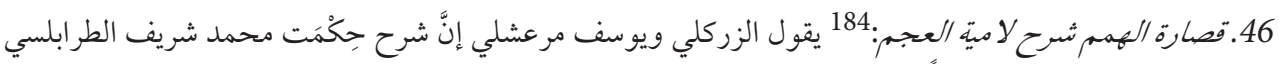

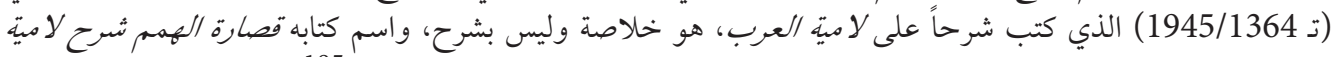

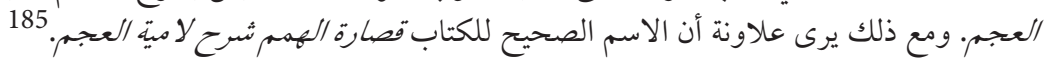

47.ترشيح القلم في لامية العجم:186 نُشرت طبعات عدّة لهذا الشرح الذي كتبه ولدان فائق أفندي (ت 1925). 48.أنمونج الحكمب شرح لامية العجم:187 يكتفي الحبشي بذكر أنَّ اسم كاتب هذا الشرح نور الدين. 49. شرح لامية الطنرائي (لامية العجم):188 وقد نُشر هذا الشرح الذي كتبه صاحب يونس الموسوي عام 2011 في

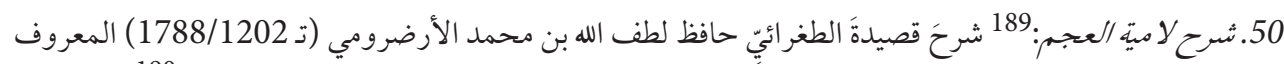

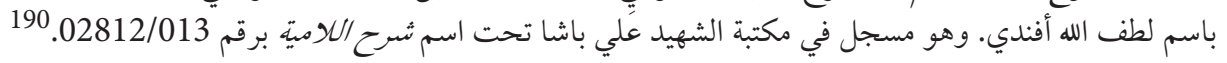

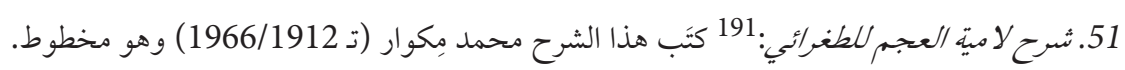

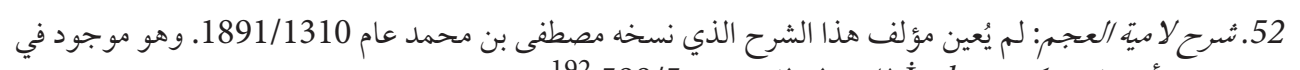

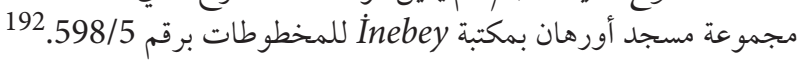
53. ثرح لامية العجم: لم يُعين مؤلف هذا الشرح. 193 54. الوردة على لامية العجم: لم يعين مؤلف هذا الشرح. 194

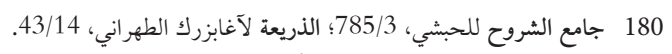

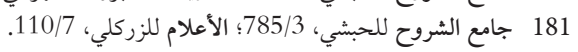
.EK-1/191، “Betâvirî”، ‘Bulut 182

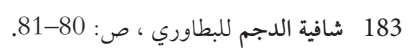
184 جامع الشروح للحبشي، 785/3؛ الأعلام للزركلي، 268/2؛ نثر الجواهر للمرعشلي،، 394؛ نظرات للعلاونة، 52/2؛ معجم الأدباء للجبوري، 250/2. 185 109/43، “Vildan Fâik Efendi” ، Güldöşüren 186 187 188 188 “Erzurumlu Müfessir Lütfullah Efendi” ، Yildırım، 189 .Göğsügür Lütfullah Efendi 」 Şerhu Lâmiyyeti'l- 'acem 190 https://www.almoajam.org/lists/inner/6907 (02.03.2021) 191 192 193 194 جامع الشروح للحبشي، 195/3. 
55. ثسرح لامية العجم: ولم يعين مؤلف هذا الشرح الذي نَسخَه أحمد بن محمد بن علي المول عامَ 1179هـ. 195

$$
\begin{aligned}
& \text { 56. ثرح لامية العجم: لم يعين مؤلف هذا الشرح. } 196 \\
& \text { 57. شرح لامية العجم: لم يعين مؤلف هذا الشرح. } 197
\end{aligned}
$$

58. شرح لامية العجم: لم يعين مؤلف هذا الشرح، والشرح مسجل تحت اسم شرح لامي العجمي. 198

$$
\text { 60. 50.نبة من ثرح لا مية العجم: لم يعين مؤلف هذا الشرح. } 199
$$

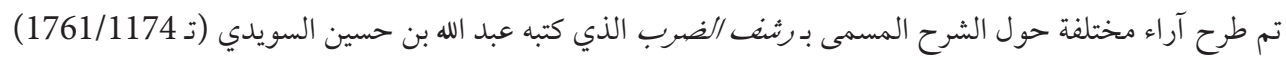

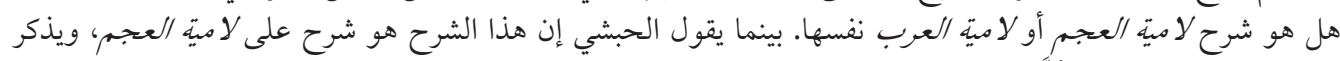

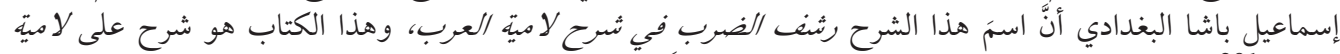

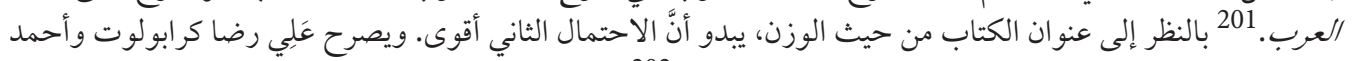

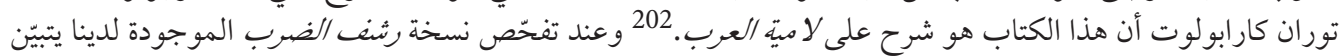
لنا أن الكتاب هو شرح لـ لامية العرب.

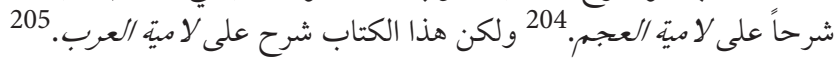
الخاتمة

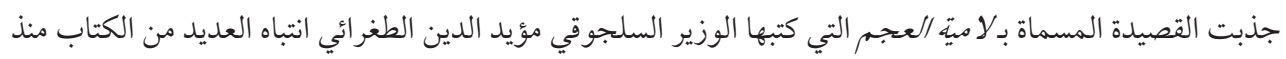

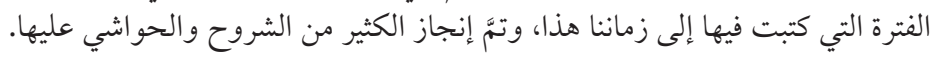

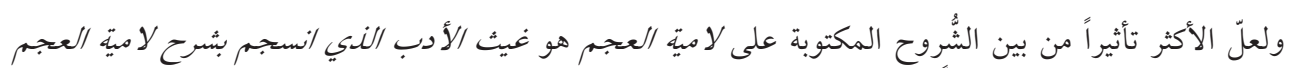

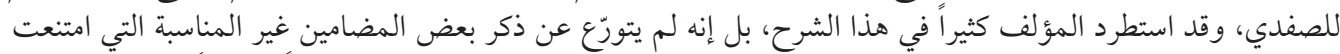

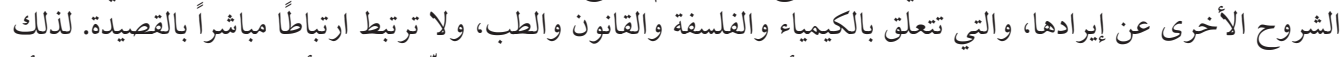

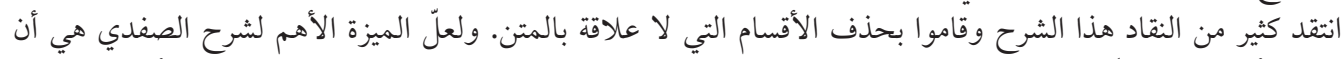

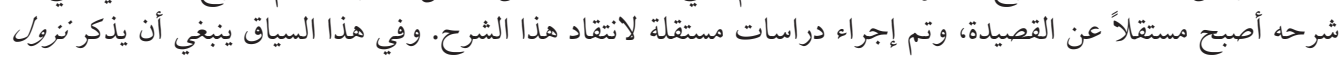

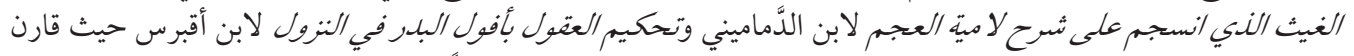

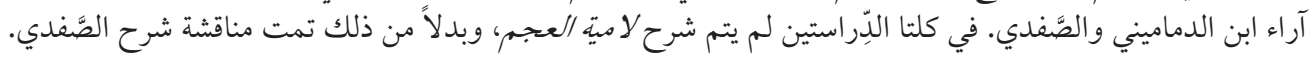

195

196 شرح لامية العجم لمؤلف مجهول، Beyazit Kütüphanesi لامجية العزول، 195

197 شرح لامية العجم لمؤلف مجهول، Beyazıt Kütüphanesi (Veliyüddin Efendi).

198

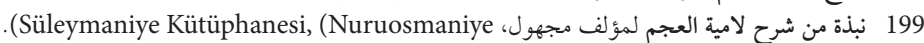

200 شرح لامية العجم لمؤلف مجهول، Süleymaniye Kütüphanesi, (Hasan Hüsnü Paşa)

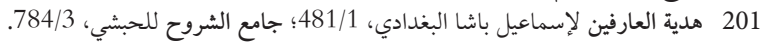

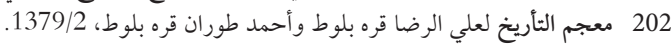
https://ketabpedia.com/\%D8\%AA\%D8\%AD\%D9\%85\%D9\%8A\%D9\%84/\%D8\%B1\%D8\%B4\%D9\%81-\%- 203 D8\%A7\%D9\%84\%D8\%B6\%D8\%B1\%D8\%A8-\%D9\%81\%D9\%8A-\%D8\%B4\%D8\%B1\%D8\%AD-\%D9\%84\%D8\%A7\%D9\%85\%D9\%8A\%D9\%87-\%D8\%A7\%D9\%84\%D8\%B9\%D8\%B1\%D8\%A8\%D8\%9B\%D8\%A7\%-

(D8\%A8\%D9\%88\%D8\%A7\%D9\%84\%D8\%A8\%D8\%B1\%D9\%83/ (02.03.2021

204

205 بلاد شنقيط للنحوي، ص: 582. 


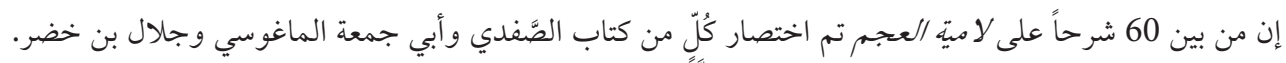

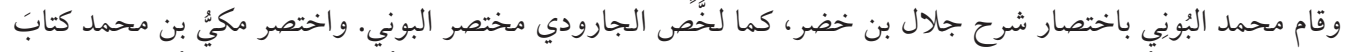

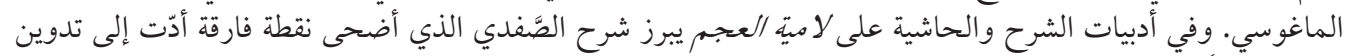

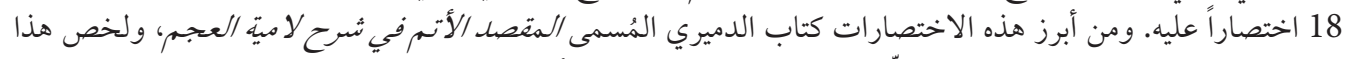

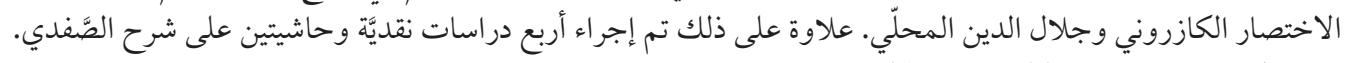

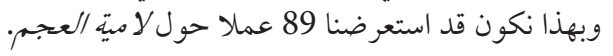


المراجع

اعتراضات بدر الدين الدماميني ومناقشاته في نزول الغيث لصلاح الدين الصفدي في شرحه (الغيث المسجم في شرح لامية

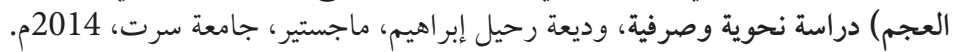

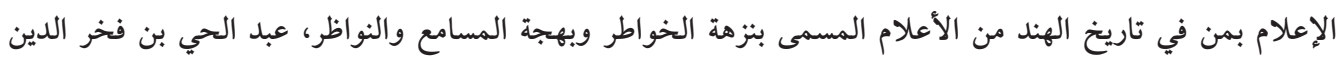

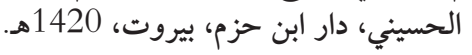

الأعلام قاموس تراجم، خير الدين بن محمود بن محمد بن علي بن فارس الزركلي، دار العلم للملايين، بيروت، 2002م. الاستقصاء لأخبار دول المغرب الأقصى، أحمد بن خالد الناصري، دار البيضاء.

إيضاح المبهم من لامية العجم، محمد بن أبي بكر ابن جماعة، Beyazıt Kütüphanesi،Beyazıt Umumi، 05390 .

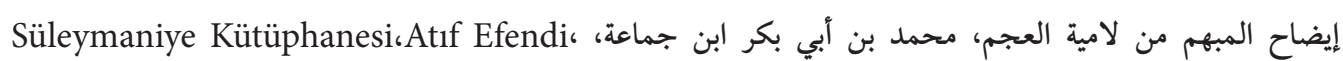
.001-02192

إيضاح المكنون في الذيل على كشف الظنون، إسماعيل باشا البغدادي، دار إحياء التراث العربي، بيروت. بغية الطلب في تاريخ حلب، عمر بن أحمد بن أبي جرادة ابن العديم، دار الفكر، بيروت. بغية الوعاة في طبقات اللغويين والنحاة، عبد الرحمن بن أبي بكر جلال الدين السيوطي، المكتبة العصرية، لبنان. بلاد شنقيط المنارة والرباط، الخليل النحوي، المنظمة العربية للتربية والثقافة والعلوم، تونس، 1987م. تاريخ الادب العربي- عصر الدول والإمارات الجزيرة العربية العراق وإيران، شوقي ضيف، دار المعارف، القاهرة. تاريخ الأدب العربي، كارل بروكلمان، ترجمة: عبد الحليم النجار، الهيئة المصرية العامة للكتاب، القاهرة، 1993م. تاريخ الجزائر الثقافي، أبو القاسم سعد الله، دار الغرب الإسلامي، بيروت.

التحفة اللطيفة في تاريخ المدينة الشريفة، محمد بن عبد الرحمن بن محمد السخاوي، دار الكتب العلمية، بيروت، 1414 هــ

تحكيم العقول بأفول البدر بالنزول لابن أقبرس دراسة وتحقيق، عادل بن محمد الرفاعي، الماجستير، الجامعة الأردنية، 2010

تحكيم العقول بأفول البدر بالنزول، علي ابن أقبرس، الدار المالكية، تونس، 1437هـ. تراجم المؤلفين التونسيين، محمد محفوظ، دار الغرب الإسلامي، بيروت، 2003هـ.

جامع الشروح والحواشي معجم شامل لأسماء الكتب المشروحة في التراث الأسلامي و بيان شروحها، عبدالله محمد

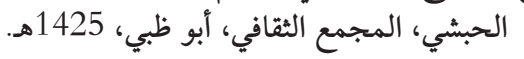

الدر الذي انظم من شرح لامية العجم، أبو الوفاء الأرضي، Süleymaniye Kütüphanesi Esad Efendi، 02801 الدرر الكامنة في أعيان المائة الثامنة، أحمد بن علي بن محمد الكناني ابن حجر العسقلاني، دائرة المعارف العثمانية،

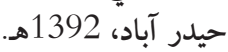

الديباج المذهب في معرفة علماء أعيان المذهب، ابن فرحون المالكي، دار التراث للطبع والنشر، القاهرة، 1972م. ديوان الإسلام، شمس الدين أبو المعالي محمد بن عبد الرحمن ابن الغزي، دار الكتب العلمية، بيروت، 1411هـ. 
الذريعة إلى تصانيف الشيعة، آغابزرك الطهراني، دار الأضواء، بيروت، 1403هـ. سلم الوصول إلى طبقات الفحول، مصطفى بن عبد الله كاتب جلبي حاجي خليفة، معهد البحوث والدراسات العربية، إسطنبول، 2010م.

سوس العالمة، محمد المختار السوسي، مؤسسة بنشرة للطباعة والنشر، المغرب، 1984م.

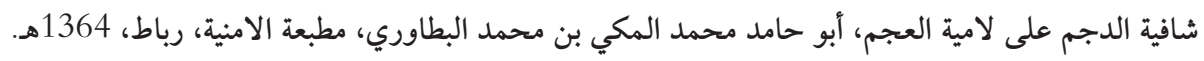

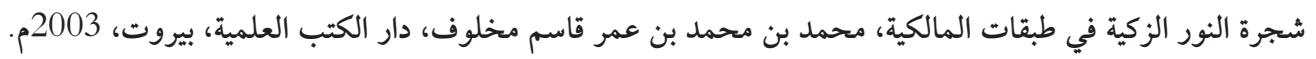

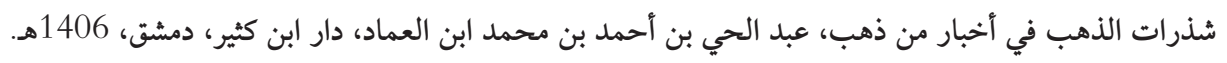

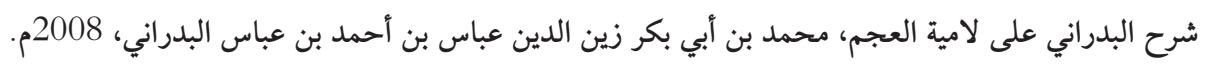

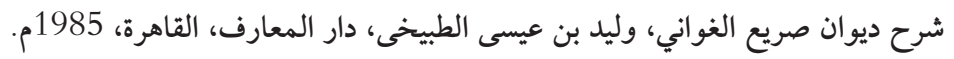

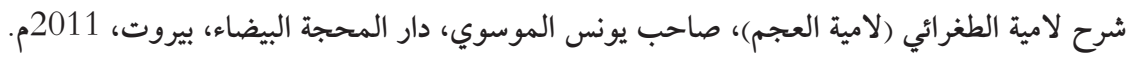

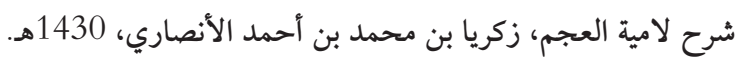
شرح لامية العجم، عبد الرحمن بن أبي بكر جلال الدين السيوطي، مكتبة الآداب، القاهرة.

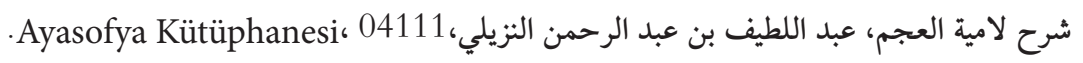
شرح لامية العجم، لبيب أفندي، طبع خانه عامره، إسطنبول.

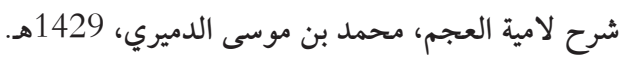

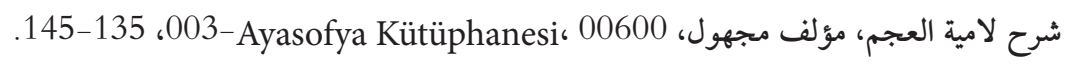

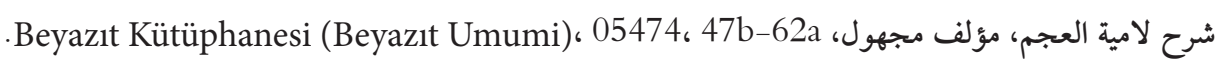

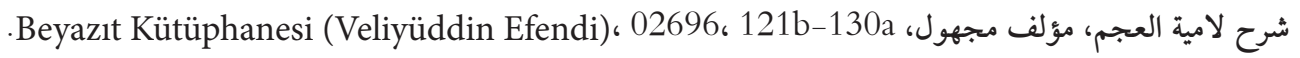

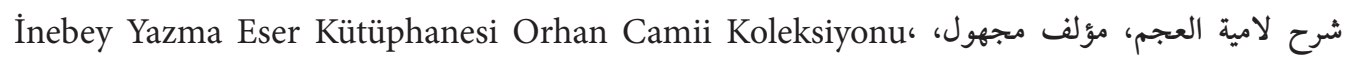
1/5557

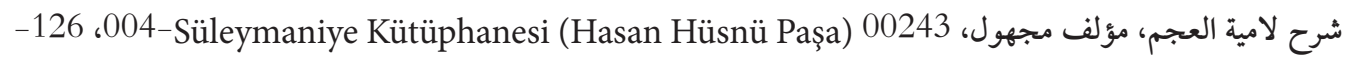

شرح لامية العجم، مؤلف مجهول، 132 126 -013-Süleymaniye Kütüphanesi (Nuruosmaniye)، 04961

شüleymaniye Kütüphanesi، Hacı Mahmud Efendi شرح لامية العجم، مؤلف مجهول،

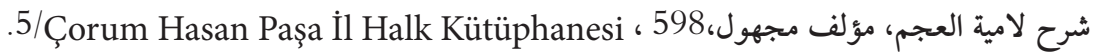
شروح لامية العجم دراسة تحليلية نقدية، إبراهيم محمد منصور، المركز المصري العربي للصحافة والنشر والثوزيع، القاهرة، 1998م.

الشعر بين التطور والجمود في العصرين البويهي والسلجوقي، نجاة محمد عبد الماجد العبّاسي،. دكتوراة، جامعة أم القرى، 1989م. 
الصفدي وشرحه على لامية العجم دراسة تحليلية، نبيل محمد رشاد، مكتبة الآداب، القاهرة، 2001هـ. الضوء اللامع لأهل القرن التاسع، محمد بن عبد الرحمن بن محمد السخاوي، دار مكتبة الحياة، بيروت.

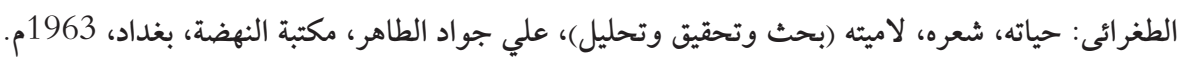

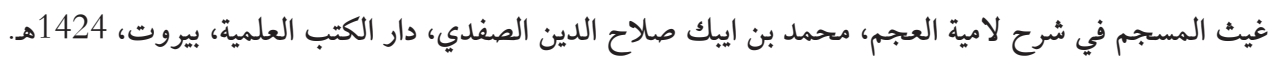
فتح المعجم من لامية العجم، محمد بن مصطفى بوجندار، 1334هـ لهيه.

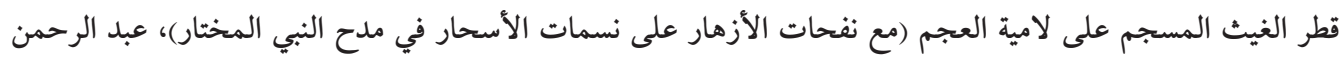

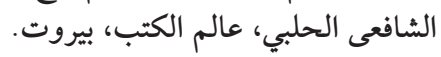

كتاب الأرب من غيث الأدب، محمد بن ايبك صلاح الدين الصفدي، المطبعة العثمانية، 1897م. يُروب

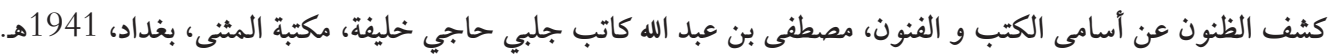

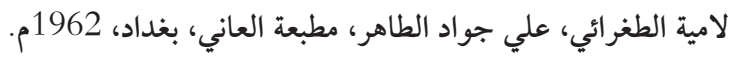

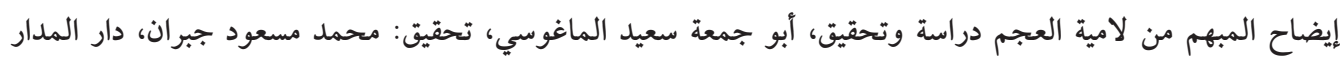

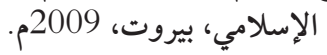

مجلة التربية والعلم، ((وزير الموصل مؤيد الدين الطغرائي: دراسة في سيرته ونشاطه العلمي))، مها سعيد حميد، العدد 5 5 5 2012، ص: 175-92.

مجلة الجامعة الإسلامية، ((شرح لامية العجم لأبي البقاء عبد الله بن الحسين العكبري (538-616هـ))، محمود محمد

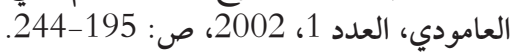

مجلة الجامعة الإسلامية، ((شرح لامية العجم للشيخ العالم زين العابدين بن محيي الدين الأنصاري (توفي 1068

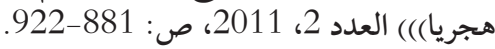

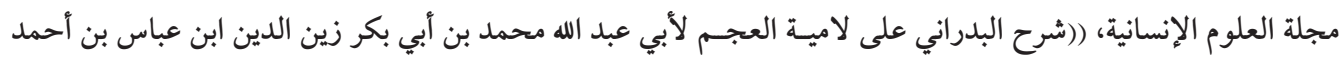

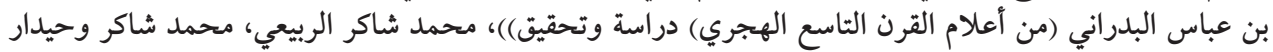

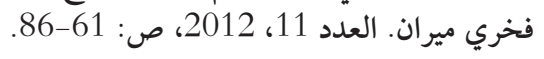

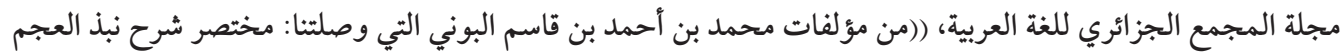

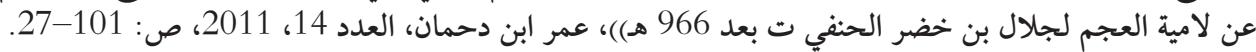

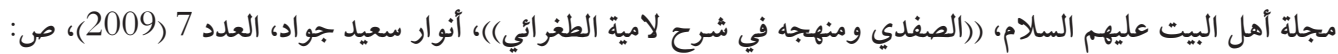
.323-288

مجلة رفوف، ((منهج ابن أب المزمري وأسلوبه في مؤلفه (نفث القلم بشرح لامية العجم)))، أميرة خالدي، العدد 2،

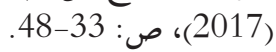

مجلة كلية الدعوة الإسلامية، ((مختصر شرح لامية العجم لمكي بن محمد)) عبد الله بن علي السويي، العدد 22 (2005) ص: 202- (40-40.

مختصر شرح لامية العجم ، محمد بن موسى الدميري، دار المنهاج، جدة.

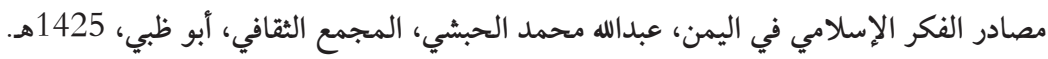


معجم الأدباء إرشاد الأريب إلى معرفة الأديب، ياقوت الحموي، دار الغرب الإسلامي، بيروت، 1999م.

معجم الأدباء من العصر الجاهلي حتى سنة 2002م، كامل سلمان الجبوري، دار الكتب العلمية، بيروت.

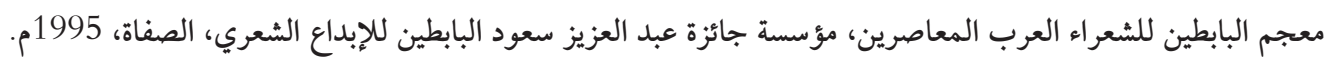

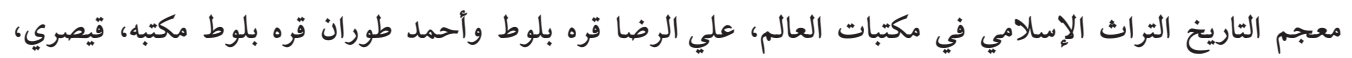
2001/1422

معجم المطبوعات العربية والمعربة، يوسف بن إليان بن موسى سركيس، مطبعة سركيس، مصر، 1346هـ. معجم المؤلفين، عمر رضا كحالة، مكتبة المثنى، بيروت.

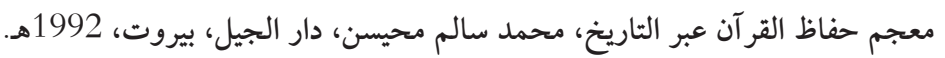
المعسول، محمد المختار السوسي، دار البيضاء، 1396هـ مهرك.

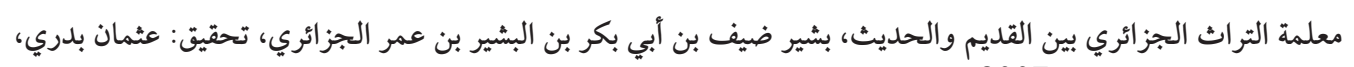

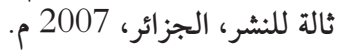

المقصد الأتم في شرح لامية العجم، محمد بن موسى الدميري، دار الرضوان، عمّان، 1433هـ.

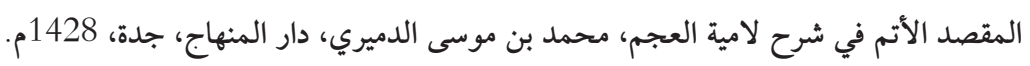

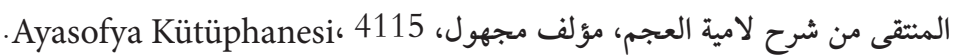
موسوعة التراجم المغربية، أبو العباس أحمد بن محمد بن من أحمد بن بن محمد القرشي.

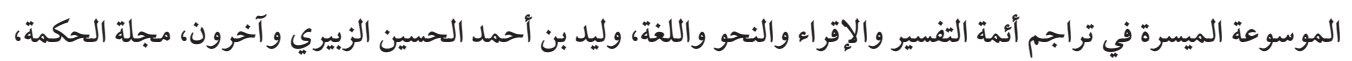
مانشستر، 1424هـ

موسوعة طبقات الفقهاء في قرن الرابع العشر، اللجنة العلمية، مؤسسة الإمام الصادق، قوم، 1420هـ.

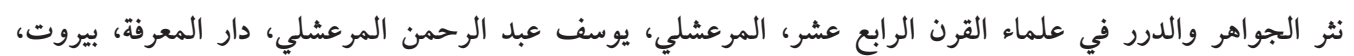
1427هـ

نزول الغيث الذي انسجم في شرح لامية العجم، محمد بن أبي بكر بدر الدين الدماميني، دار المالكية للنشر، تونس، 1437هـ.

نشر العلم في شرح لامية العجم، جمال الدين محمد بن عمر بن مبارك الحضرمي، دار المنهاج، جدة، 1433هـ.

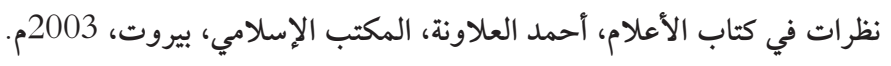

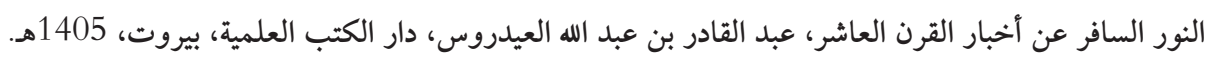

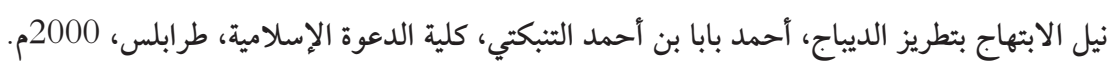

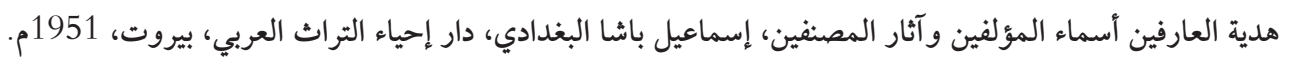

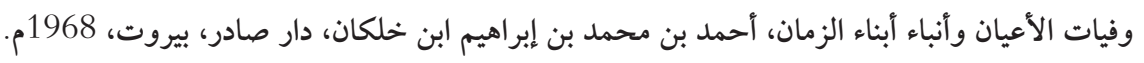




\section{Kaynakça}

Akpınar, Cemil. “Kefevî Hüseyin Efendi”. DİA, XXV, 186-8.

Ali b. el-Kasım et-Taberî. Hallü’l-mübhem ve'l-mu'cem fî şerhi Lâmiyyeti'l-acem. Süleymaniye Kütüphanesi, Hacı Selim Ağa.

Ali el-Minyâvî, Muhammed Efendi. Tuhfetürr-râî li-Lâmiyyeti't-Tugrâî. Bulak: Matba'atü’l-Emîriyye, 1313/1896.

el-Alâvine, Ahmed. Nazarât fî kitâbi'l-A 'lâm. Beyrut: el-Mektebü'l-İslâmî, 2003.

el-Âmûdî, Mahmud Muhammed. "Şerhu Lâmiyyeti'l-acem li-Ebi'l-Bekâ Abdillah b. el-Hüseyin el-Ukberî (538-616 h.), dirâse ve tahkîk”. Mecelletü’l-Câmi 'ati'l-İslâmiyye, 2002, sy. 1, s. 195-244.

el-Âmûdî, Mahmud Muhammed. "Şerhu Lâmiyyeti'l-acem liş-şeyhi'l-âlim Zeynilabidin b. Muhyiddin el-Ensârî (tüvüffiye 1068 Hicriyyen)- Tahkîk ve Dirâse”. Mecelletu Câmi'ati'l-İslâmiyye (Silsiletü’ddirâsâti'l-insâniyye), 2011, sy. 2, s. 881-922.

Arslan, Şükrü. “Mahallî”. DİA, XXVII, 326-7.

el-Ayderûsî, Ebû Abdülkadir b. Şeyh b. Abdullah. Târîhu'n-nûri's-sâfir an ahbâri'l-karni’l-âş̧ir. Beyrut: Dâru'l-Kütübi'l-İlmiyye, 1405/1985.

Bağdatlı İsmail Paşa. Îzâhu'l-meknûn fî zeyl-i alâ Keşfü̉z-zunûn an esâmi'l-kütüb ve’l-fünûn. I-II, Beyrut: Dâru İhyâi't-Türâsi'l- 'Arabî, ts.

Bağdatlı İsmail Paşa, İsmail b. Muhammed. Hediyyetü'l-ârifîn: esmâü'l-müellifîn ve âsâru'l-musannifîn. I-II, Lübnan: Dâru İhyâi't-Türâsi'l-Arabî, 1951.

Bakırcı, Selami. “Lamiyyetu'l-Arab ve Lâmiyyetu'l-Acem Arasında Bir Mukayese”. Nüsha, 2010, sy. 31, s. 131-54.

Bakırcı, Selami. “Ukberî̀. DİA, XLII, 66-7.

Bulut, Ali. "Betâvirî”. DİA, EK-1, 191-2.

el-Bedrânî, Muhammed b. Ebî Bekir Zeynüddîn b. Abbas. Şerhu'l-Bedrânî alâ Lâmiyyeti'l-acem, 2008.

el-Betâvirî, Muhammed el-Mekkî b. Muhammed b. Ali. Şâfiyetü̉d-dücem alâ Lâmiyyeti'l-acem. Rabat: Matba atü'l-Emniyye, 1364/1945.

Brockelmann, Carl. Geschichte der Arabischen Litteratur (Târîhu'l-edebi'l-Arabî) (trc. es-Seyyid Ya‘kûb Bekir - Ramazan Abdüttevvâb). I-X, Kahire: el-Heyetü'l-Mısriyyetü'l-Âmme li'l-Kitâb, 1993.

Bûcendâr, Muhammed b. Mustafa. Fethu'l-mu'cem min Lâmiyyetil-acem. Fas: Matba 'atu Cerîdeti Sade’lMağrib, 1334/1915.

el-Cebûrî, Kamil Süleyman. Mu'cemü’l-üdebâ mine’l-asril-câhilî hattâ senete 2002. I-VII, Beyrut: Dâru’lKütübi'l-İlmiyye, ts.

Celaleddin b. Hızır. Nebzü'l-acem an Lâmiyyeti'l-acem, ts.

Cengiz, Mehdi. "Bir Kasideden Onlarca Yeni Yapıta: Tuğrâînin Lâmiyyetu’l-'Acem’ine Yapılan Tahmîs, Muâraza (Nazire) ve Taştîrler." Dinbilimleri Akademik Araştırma Dergisi, 2021, sy. 21, s. 485-505.

Cevâd, Envâr Saîd. "es-Safedî ve menhecühû fî Şerhi Lâmiyyeti'l-acem”. Mecelletü ehli'l-beyt aleyhi's-selâm, 2009, sy. 7, s. 288-323.

el-Cezâirî, Abdullah b. Ali Nureddin b. Nimetullâh. Tezyîlü Sülâfeti'l-asr. Necef: el-Mektebetü'l-Edebiyyetü'lMuhtassa, ts.

el-Cezâirî, Beşir b. Dayf b. Ebî Bekir b. Beşir. Kitâbu Ma 'lemetü't-türâsi'l-Cezâirî beyne'l-kadîm ve'l-hadîs (ed. Osman Bedri). Cezair: Mektebetu Sâla, 2007.

Cezzâr, Fikri Zekî. Medâhilü'l-müellifîn ve'l-a 'lâmü'l-Arab hatta âm 1215 h. /1800 m. Riyad: Mektebetü'lMelik Fehd el-Vataniyye, 1413/1992. 
Dayf, Şevkî. Târîhu'l-edebi'l-Arabî: Asru'd-düvel ve'l-imârât: el-Cezîretü'l-Arabiyye, el-Irâk, Îrân. Kahire: Dâru'l-Ma'ârif, ts.

ed-Demâmînî, Ebû Abdullah Bedrüddîn Muhammed b. Ebî Bekir b. Ömer el-Mahzûmî el-İskenderî. Nüzûlü'l-Gaysilllezî insecem alâ şerhi Lâmiyyeti'l-acem. Süleymaniye Kütüphanesi, Laleli, 01949.

-------. Nüzûlül-Gaysilllezî insecem alâ şerhi Lâmiyyeti’l-acem. Süleymaniye Kütüphanesi, Reîsülküttâb Mustafa Efendi, 00932.

-------. Nüzûllül-Gaysilllezî insecem fî şerhi Lâmiyyeti'l-acem. Tunus: ed-Dâru'l-Mâlikiyye, 1437/2016.

ed-Demîrî, Kemâlüddîn Muhammed b. Musa. el-Maksadü'l-etem fî şerhi Lâmiyyeti'l-acem. Dâru’r-Ridvân li’n-Neşr ve’t-Tevzî̀, 1433/2012.

----.-. Muhtasaru Şerhi Lâmiyyeti'l-acem. Cidde: Dâru'l-Minhâc, 1428/2007.

------. Şerhu Lâmiyyeti'l-acem, 2008.

Durmuş, İsmail. “Safedî”. DİA, XXXV, 447-50.

el-Lecnetü'l-ilmiyye. Mevsû 'atu tabakâti'l-fukahâ fîl'-karni'l-hâdi aşer. I-XIV, Kum: Müessesetü'l-İmâm esSâdık, 1420/1999.

Er, Rahmi. “Tuğrâî”. DİA, XLI, 339-41.

Göğsügür Lütfullah Efendi, Lütfullah b. Muhammed el-Erzurumi. Şerhu Lâmiyyeti’l-acem. Süleymaniye Kütüphanesi, Şehit Ali Paşa, 02812-013.

Gonca, Enise Sema. İstanbul Üniversitesi Kütüphanesinde Bulunan Arap Şiirine Dair Arapça Yazmalar (Sad ص (yüksek lisans tezi, 2011). İstanbul Üniversitesi SBE.

Güldöşüren, Arzu. "Vildan Fâik Efendi”. DİA, XLIII, 108-9.

el-Habeşî, Abdullah Muhammed. Câmi 'u'ş-şurûh ve'l-havâşî: mu 'cemun şâmil li-esmâi'l-kütübi'l-meşrûha fî̀-türâsi'l-İslâmî ve beyâni şurûhihâ. I-III, Abudabi: el-Mecma 'u's-Sekâfî, 1425/2004.

------. Mesâdiru'l-fikri'l-İslâmî fi'l-Yemen. Abudabi: el-Mecma 'u’s-Sekâfî, 1425/2004.

el-Hadramî, Cemaleddin Muhammed b. Ömer b. Mübârek. Neşrü'l-alem fi şerhi Lâmiyyeti'l-acem. Cidde: Dâru'l-Minhâc, 1433/2012.

el-Halebî, Abdurrahman. Katru'l-gaysi'l-münsecem alâ Lâmiyyeti'l-acem (Nefehâtü'l-ezhâr alâ nesemati'leshâr fî medhi'n-nebiyyi'l-muhtâr şerhi'l-Bedî'iyye ile birlikte). Beyrut: İlemu'l-Kütüb, ts.

el-Hamevî, Ebû Abdullah Şihâbüddîn Yâkût b. Abdullah. Mu'cemü'l-üdebâ (İrşâdü’l-erîb ilâ ma 'rifeti’ledîb). I-VII, Beyrut: Dâru'l-Garbi'l-İslâmî, 1999.

Hamîd, Mahâ Said. "Vezîrü'l-Mevsil Müeyyidüddîn et-Tugrâî -dirâse fî sîretihi ve neşâtihi'l-ilmî-". Mecelletü't-Terbiye ve'l-İlm. 2012, sy. 5, s. 175-92.

el-Hasenî, eş-Şerîf Abdülhay b. Fahruddîn. el-İ 'lâm bi-men fî târihi'l-Hind mine'l-a 'lâm el-müsemmâ biNüzhetül-havâtır ve behcetü’l-mesâmi' venn-nevâzır. I-VIII, Beyrut: Dâru İbn Hazm, 1420/1999.

Hilal, Grgün. "Rifâa et-Tahtâvî”. DİA, XXXV, 95-7.

İbn Akbers, Alaeddin Ali b. Muhammed eș-Şafîi. Tahkîmü’l-ukûl bi-ufûli’l-nedri fîn-nuzûl. Tunus: edDâru'l-Mâlikiyye, 1437/2016.

İbn Ahmed Hüseyin ez-Zübeyrî, Velîd v.dğr. el-Mevsû 'atü'l-müyessere fî̀ terâcimi eimmeti’t-tefsîr ve’l-ikrâ ven-nahv ve'l-luga. I-III, Medine: Mecelletü'l-Hikme, 1424/2003.

İbn Cemâ‘a, Muhammed b. Ebî Bekir. Îzâhu'l-mübhem min Lâmiyyeti'l-acem. Beyazıt Kütüphanesi, Beyazıt Umumi, 05390. Îzâhu'l-mübhem min Lâmiyyeti'l-acem. Süleymaniye Kütüphanesi, Atıf Efendi. 02192-001. 
İbn Dahmân, Ömer. "Min müellefâti Muhammed b. Ahmed b. Kasım el-Bûnî elletî vasalatne: Muhtasaru Şerhi ((Nebzi'l-acem an Lâmiyyeti'l-acem)) li Celâl b. Hızır el-Hanefî (tüvüffiye ba de 966 hicriyyen)”. el-Mecme 'u'l-Cezâirî li'l-Luğati'l- 'Arabiyye, 2011. sy. 14, s. 101-27.

İbn Ferhûn, Ebü'l-Vefa Burhaneddin İbrahim b. Ali b. Muhammed. ed-Dîbâcü̉l-müzheb fî ma'rifeti a yân ulemâ'i'l-mezheb. I-II, Kahire: Dâru’t-Türâs li’t-Tab`ve’n-Neşr, 1391/1972.

İbn Hacer el-Askalânî, Ebü’l-Fazl Şihâbüddîn Ahmed b. Ali b. Muhammed. ed-Düreru'l-kâmine fî a 'yâni'lmieti's-sâmine (nşr. Muhammed Abdülmuîd Dân). I-VI, Hindistan: Meclisu Dâireti'l-Me'ârifi'lOsmâniyye, 1392/1972.

İbn Hallikân, Ebü'l-Abbas Şemseddin Ahmed b. Muhammed. Vefeyâtü'l-a'yân ve enbâu ebnâi'z-zamân. I-VII, Beyrut: Dâru Sâdır, 1968.

İbn Kesîr, Ebü'l-Fida İmâdüddin İsmail b. Ömer. el-Bidâye ve’n-nihâye. I-XII, Beyrut: Dâru İhyâit-Türâsi'l-Arabî, ts. İbnü'l-Gazzî, Ebü'l-Meâlî Şemseddin Muhammed b. Abdurrahman. Dîvânü’l-İslâm. I-IV, Beyrut: Dâru’lKütübi'l-İlmiyye, 1411/1990.

İbnü'l-Verdî, Ebû Hafs Zeynüddin Ömer b. Muzaffer b. Ömer. Târîhu İbni’l-Verdî (Tetimmetü’l-Muhtasar fî ahbâri'l-beşer). Beyrut: Dâru'l-Kütübi'l-İlmiyye, 1417/1996.

İbnü'l-Adîm, Ebü’l-Kâsım Kemâleddin Ömer b. Ahmed. Bugyetü't-taleb fî târîhi Haleb. I-XII, Beyrut: Dâru'l-Fikr, ts.

İbnü'l-İmâd, Ebü'l-Felâh Abdülhay b. Ahmed b. Muhammed. Şezerâtü'z-zeheb fî ahbâri men zeheb. I-X, Dımaşk: Dâru İbn Kesîr, 1986.

İbrahim, Vedîa Rahîl. İ'tirâdâtü Bedriddîn ed-Demâmîn̂̀ ve Münâkaşâtühû fî (Nüzûlü'l-gays) li-Salâhiddîn es-Safedî fî Şerhihi (el-Gaysü'l-müseccem fî şerhi Lâmiyyeti'l-acem) Dirâse Nahviyye ve Sarfiyye (yüksek lisans tezi, 2013). Câmi' atü Sirte.

İzgi, Cevat. "Demîrî". DİA, IX, 152-3.

Karabulut, Ali Rıza - Ahmet Turan Karabulut. Mu'cemü't-târîhi't-türâsi'l-İslâmî fi mektebâti'l- 'âlem: el-mahtûtât ve'l-matbû'ât (Dünya kütüphanelerinde mevcut İslam kültür tarihi ile ilgili eserler ansiklopedisi). I-VI, Kayseri: Mektebe Yayınları, 1422/2001.

Kallek, Cengiz. "İbn Cemâa, Muhammed b. Ebû Bekir”. DİA, XIX, 394-95.

Karaaslan, Nasuhi Ünal. "İbn Hicce”. DİA, XX, 65-6.

Katib Çelebi, Hacı Halife Mustafa b. Abdullah. Keş̧üz-zunûn an esâmi'l-kütüb ve’l-fünûn. I- II, Bağdat: Mektebetül-Müsennâ, 1359/1941.

------. Süllemü’l-vüsûl ilâ tabakâti'l-fuhûl. I-V, İstanbul: Ma`hedü’l-Buhûs ve’d-Dirâsâti'l-Arabiyye (İslam Tarih, Sanat ve Kültür Araştırma Merkezi (IRCICA)), 2010.

Kehhâle, Ömer Rıza. Mu 'cemü'l-müellifîn. I- XV, Beyrut: Mektebetü'l-Müsennâ, ts.

el-Kurâşî, Ebü'l-Abbâs Ahmed b. Muhammed b. Ahmed. Mevsû 'atü'-terâcimi'l-Magribiyye, ts.

Lebib Efendi. Değişmedi gecenin rengi Şerh-i Lâmiyyetü'l-Acem- Tuğrâînin Lâmiyyetü'l-Acem Kasidesinin Şerhi. İstanbul: Büyüyen ay, 2019.

------. Şerh-i Lâmiyyeti'l-acem. İstanbul: Tabhane-i Âmire, 1271/1855.

el-Mâgûsi, Ebû Cuma Saîd. Îzâhü'l-mübhem min Lâmiyyeti'l-acem. Dâru'l-Medâri'l-İslâmî, 2009.

Mahfûz, Muhammed. Terâcimü’l-müellifîne't-Tûnisiyyîn. I-V, Beyrut: Dâru'l-Garbi'l-İslâmî, 1994.

Mahlûf, Muhammed b. Muhammed b. Ömer el-Münestiri Muhammed. Şeceretün-nûri'z-zekiyye fî tabakati'l-Mâlikiyye. I-III, Beyrut: Dâru'l-Kütübi'l-İlmiyye, 2003.

Mansur, İbrahim Muhammed. Şurûhu Lâmiyyeti'l-acem, dirâse tahlîliyye nakdiyye. Mısır: el-Merkezü’lMisriyyü’l- 'Arabî li’s-Sahâfe ve’n-Neşr ve’t-Tevzî̀, 1418/1998. 
Mar'aşlî, Yusuf. Nesru'l-cevâhir ve'd-dürer fî ulemâi'l-karni'r-râbi' aşer: 'İkdü'l-cevher fî ulemâi'r-rub 'i'l-evvel mine'l-karni'l-hâmis aşer. I-II, Beyrut: Dâru'l-Ma 'rife, 1427/2006.

Meçhul müellif. Şerhu Lâmiyyetil'-acem. İnebey Yazma Eser Kütüphanesi Orhan Camii Koleksiyonu, 16 Or 557/1.

Meçhul müellif. Şerhu Lâmiyyeti'l-acem. Çorum Hasan Paşa İl Halk Kütüphanesi, 19 Hk 598/5.

Meçhul müellif. Şerhu Lâmiyyeti'l-acem. Süleymaniye Kütüphanesi, Hacı Mahmud Efendi (Yahya Efendi Dergah1), 05084-002.

Meçhul müellif. Şerhu Lâmiyyeti'l-acem. Beyazıt Kütüphanesi (Beyazıt Umumi), ts. 05474.

Meçhul müellif. Şerhu Lâmiyyeti'l-acem. Beyazıt Kütüphanesi (Veliyüddin Efendi), ts. 02696.

Meçhul müellif. Şerhu Lâmiyyeti'l-acem. Süleymaniye Kütüphanesi, Nuruosmaniye, ts. 04961-013.

Meçhul müellif. Şerhu Lâmiyyeti'l-acem. Süleymaniye Kütüphanesi, Hasan Hüsnü Paşa, ts. 00243-004.

Meçhul müellif. Şerhu Lâmiyyeti'l-acem. Ayasofya Kütüphanesi, ts. 00600-003.

el-Meşrefî, Muhammed b. Muhammed b. Mustafa. el-Hulelü'l-behiyye fi mülûki'd-devleti'l-aleviyye. I-II, Rabat: Vizâretü'l-Evkâf veş-Şuûni'l-İslâmiyye, 1425/2005.

Muhammed Reşad, Nebîl. es-Safedî ve şerhuhu alâ Lâmiyyeti'l-acem: dirâse tahlîliyye. Kahire: Mektebetü’lÂdâb, 1421/2001.

Muhaysin, Muhammed Sâlim. Mu'cemu huffâzi'l-Kurân abre’t-târîh. I-II, Beyrut: Dâru'l-Cîl, 1992.

el-Mûsevî, Sâhib Yunus. Şerhu Lâmiyyeti't-Tugrâî (Lâmiyyetü'l-acem). Beyrut: Dâru’l-Mehacceti'l-Beydâ li't-Tibâ'a ve’n-Neşr ve’t-Tevzî̀, 2011.

Mustafa, Mahmûd. İ'camü'l-a 'lâm. Beyrut: Dâru'l-Kütübi'l-İlmiyye, 1403/1983.

Mu 'cemü’l-Bâbitîn lişş̧ư 'arâi'l- 'Arabi'l-mu 'âsırîn. Safat: Müessesetü Câize Abdülazîz Su udi'l-Babitin li'lİbda 'işs-Şieri, 1995.

en-Nahvî, el-Halil. Bilâdü Şenkît el-menâra ve’r-rabât. Tunus: Mektebetü'l-Müntedâ el-İslâmî, 1987.

Nüveyhiz, Âdil. Mu'cemü'l-müfessirîn min sadri'l-İslâm hatta'l-asri'l-hâdır. Beyrut: Müessesetu Nuveyhizi'sSekafiyye, 1409/1988.

en-Nüzeylî, Abdüllatif b. Abdurrahman. Şerhu Lâmiyyetil-acem. Ayasofya Kütüphanesi. 04111.

Öznurhan, Halim. "Abbâsî, Abdürrahîm“. DİA, Ek-1, 5-6.

er-Rebi' î, Muhammed Şakir ve Haydar Fahrî Mîrân. “Şerhu’l-Bedrânî alâ Lâmiyyeti'l-acem li-Ebî Abdillâh Muhammed b. Ebî Bekir Zeyniddîn ibn Abbâs b. Ahmed. b. Abbâs el-Bedrânî -min a lâmi'l-karni'ttâsi' i'l-hicrî-”. Mecelletü'l-Ulûmi'l-İnsâniyye, 2012, sy. 11, s. 61-86.

er-Râvî, Necât Muhammed Abdülmacid el-Abbâsî. eş-Şi 'r beyne't-tatavvur ve'l-cumûd fi'l-asrayn el-Büveyhî $v e^{\prime}$-Selcûkî (doktora tezi, 1989). Câmi'atu-mmi'l-Kurâ.

Ribdâvî, Mahmud. İbn Hicce el-Hamevî şâ 'iran ve nâkıden. Dimaşk: Dâru Kuteybe, 1402/1982.

er-Rufầî, Adil b. Muhammed. Tahkîmu'l-ukûl bi ufûli'l-Bedri bi’n-nuzûl li-ibni Akbers dirâse ve tahkîk (yüksek lisans tezi, 2010). el-Câmi atü'l-Ürdüniyye.

Sadullah, Ebü'l-Kasım. Târîhu’l-Cezâiri's-sekâfî. I-IX, Beyrut: Dâru’l-Garbi'l-İslâmî, 1998.

es-Safedî, Ebü’s-Safâ Salâhuddîn Halîl b. Aybeg b. Abdullah. el-Gaysü'l-müscem fî Şerhi Lâmiyyeti’l-acem. Süleymaniye Kütüphanesi, Carullah Efendi, 01711.

--------. el-Gaysü'l-müseccem (müscem) fî şerhi Lâmiyyeti'l-acem. I-II, Beyrut: Dâru'l-Kütübi'l-İlmiyye, 1424/2003.

------. el-Vâfî bi'l-vefeyât. I-XXIX, Beyrut: Dâru İhyâi't-Türâsi'l-Arabî, 1420/2000.

----.-. Gaysü'l-edebi'l-Müseccem fî şerhi Lâmiyyeti'l-acem. Süleymaniye Kütüphanesi, Esad Efendi, 02800.

-------. Kitâbü'l-Ereb min Gaysi'l-edeb. Baebda: el-Matba atü’l-Osmâniyye, 1897. 
es-Sehâvî, Ebü’l-Hayr Şemsüddîn Muhammed b. Abdurrahman b. Muhammed. ed-Dav'ü'l-lâmi' li ehli'lkarni't-tâsi'. I-XII, Beyrut: Daru Mektebeti'l-Hayât, ts.

-----. et-Tuhfetü'l-latîfe fî târîhi'l-Medîneti'ş-şerîfe. I-II, Beyrut: Dâru'l-Kütübi'l-i̇lmiyye, 1414/1993.

es-Selâvî, Ebü'l-Abbas Şihâbüddin Ahmed b. Hâlid b. Hammâd. el-İstiksâ li-ahbârid-düveli'l-Magribi'l-aksâ. I-III, Dâru'l-Beydâ, ts.

Serkis, Yusuf b. İlyân b. Musa. Mu'cemü’l-matbû 'âti'l-Arabiyye ve’l-mu 'arrebe. I-II, Misır: Matba'atu Serkis, $1346 / 1928$.

es-Sûsî, Muhammed el-Muhtâr. el-Ma 'sûl. ed-Dâru'l-Beyzâ, 1396/1962.

Sûsü'l-âlime. Fas: Müessesetü Benşere li’t-Tibâ'a ve’n-Neşr, 1984.

es-Suveyî, Abdullah b. Ali. "Muhtasaru Şerhi Lâmiyyeti'l-acem li'l-Mekkî b. Muhammed”. Mecelletü Külliyyetid-Da'vet'il-İslâmiyye, 2005, sy. 22, s. 202-40.

es-Süyûtî, Ebü’l-Fazl Celâleddin Abdurrahman b. Ebî Bekir. Buğyetüll-vu'ât fî tabakâti'l-lugaviyyîn ve’nnühât. Lübnan: Mektebetü'l-Asriyye, ts.

----.- Şerhu Lâmiyyeti'l-acem li't-Tugrâî. Kahire: Mektebetü'l-Âdâb, ts.

eş-Şevkânî, Ebû Abdullah Muhammed b. Ali b. Muhammed el-Havlânî. el-Bedru't-Tâli bi-mehâsin men ba 'de'l-karni's-sâbi'. I-II, Beyrut: Dâru'l-Ma'rife, ts.

Şeyhüslam Ebü'l-Vefâ el-Urzî, Muhammed b. Ömer b. Abdülvehhâb. ed-Dürru'llezî intezam min şerhi Lâmiyyeti'l-acem. Süleymaniye Kütüphanesi, Esad Efendi, 02801.

et-Tabîhî, Velîd b. İsa. Şerhu Dîvâni Sarî’ulgavânî. Kahire: Dâru'l-Ma ârif, 1405/1985.

et-Tâhir, Ali Cevâd. et-Tugrâî, hayâtuhu-şi 'ruhu-Lâmiyyetuhu (bahs ve tahkîkve tahlîl). Bağdat: Mektebetü’nNehda, 1963.

------. Lâmiyyetü’t-Tugrâî. Bağdat: Matba aaü’l-Ânî, 1962.

et-Tahrânî, Aga Büzürg. ez-Zerî'a ilâ tesânifişs-Şì'a. I-XXV, Beyrut: Dâru'l-Advâ, 1403/1983.

Talu, Mehmet. "Bahrak“. DİA, IV, 490-1.

et-Tinbüktî, Ebü'l-Abbas Ahmed b. Ahmed b. Ahmed Baba. Neylül-ibtihâc bi-tatrîzid-dibâc. Trablus: Külliyyetü'd-Da 'veti'l-İslâmiyye, 2000.

et-Tuğrâî, Ebû İsmail Müeyyidüddin Hüseyin b. Ali b. Muhammed. Dîvânü’t-Tugrâî. Kuveyt: Dâru'l-Kalem, $1403 / 1983$.

Yâkût el-Hamevî, Ebû Abdullah Şihâbüddîn Yâkût b. Abdullah Hamevî. Mu'cemü’l-üdebâ (İş̧âdü’-erîb ilâ ma 'rifeti'l-edîb). Beyrut: Dâru'l-Garbi'l-İslâmî, 1420/1999.

el-Ya`kûbî, İbn Vazıh Ahmed b. İshak b. Ca‘fer el-Büldân. Beyrut: Dâru'l-Kütübi’l-İlmiyye, 1422/2002.

el-Ya ‘merî, Ali b. Muhammed b. Ebi'l-Kasım b. Ferhûn. "Nüzhetü’n-nazar ve tühfetü'l-fiker Şerhu Lâmiyyeti'l-acem”. Süleymaniye Kütüphanesi, Atıf Efendi, 02192-001.

Yıldırım, Zeki. “Erzurumlu Müfessir Lütfullah Efendide Nazarî Sufî Tefsir Örneği”. Atatürk Üniversitesi İlahiyat Fakültesi Dergisi, 2013, sy. 40, s. 1-40.

Zekeriyya el-Ensârî, Ebu Yahya Zeynüddin b. Muhammed b. Ahmed. Şerhu Lâmiyyeti'l- acem, 1430/2009.

ez-Ziriklî, Hayreddin b. Mahmud b. Muhammed b. Ali. el-A 'lâm. I-VIII, Beyrut: Dâru'l-İlm li'l-Melâyîn, 2002. 
http://katalog.ilke.org.tr/detay/612 (erişim tarihi: 02.03.2021).

http://katalog.ilke.org.tr/detay/741 (erişim tarihi: 02.03.2021).

http://katalog.ilke.org.tr/detay/558 (erişim tarihi: 02.03.2021).

https://ketabpedia.com/\%D8\%AA\%D8\%AD\%D9\%85\%D9\%8A\%D9\%84/\%D8\%B4\%D8\%B1\%D8\%AD\%D9\%84\%D8\%A7\%D9\%85\%D9\%8A\%D8\%A9-\%D8\%A7\%D9\%84\%D8\%B9\%D8\%AC\%D9\%85-5/ (erişim tarihi: 02.03.2021).

http://library1.kuniv.edu.kw/manuscript/Scriptsview.asp?ID=2541 5 (erişim tarihi: 02.03.2021).

http://www.almajidcenter.org/material_details.php?bId=722353\&encQry=U0VMRUNUIGJvb2tzLmlk-

LCBib29rcy50aXRsZSwgIGJvb2tzLmxhdGluX25hbWUsIG1hbnVzY3JpcHRfc3ViamVjdC50aXRsZV9lbiBhcyBzdWJqZWN0VGl0bGVFbixtYW51c2NyaXB0X3N1YmplY3QudGl0bGVfYXJfZmlsdGVyLCBtYW51c2NyaXB0X3N1YmplY3QudGl0bGVfYXIgYXMgc3ViamVjdFRpdGxlQXIsIGJvb2tzLnN0YXRlbWVudF9vZ19yZXNwb25zZSwgYm9va3MuZW5fbmFtZSBGUk9NIGJvb2tzIElOTkVSIEpPSU4gbWFudXNjcmlwdF93aXRoX3N1YmplY3QgT04gbWFudXNjcmlwdF93aXRoX3N1YmplY3QuYm9va19pZCA9IGJvb2tzLmlkIElOTkVSIEpPSU4gbWFudXNjcmlwdF9zdWJqZWN0IE9OIG1hbnVzY3JpcHRfc3ViamVjdC5pZCA9IG1hbnVzY3JpcHRfd210aF9zdWJqZWN0LnN1YmplY3RfaWQgV0hFUkUgICggbWFudXNjcmlwdF9zdWJqZWN0LnRpdGxlX2VuICA9ICfYp9mE2KPYr9ioJyAgT1IgIG1hbnVzY3JpcHRfc3ViamVjdC50aXRsZV9hciAgPSAn2KfZhNij2K/ YqCcgIE9SICBtYW51c2NyaXB0X3N1YmplY3QudGl0bGVfYXJfZmlsdGVyICA9ICfYp9mE2KPYr9ioJyApICAgQU5EIGJvb2tzLmVuX25hbWUgPSAnTWFudXNjcmlwdCcgIEdST1VQIEJZIGJvb2tzLmlk\&current $=4357 \&$ total $=4431 \& \mathrm{in}=1 \& \mathrm{by}=3 \&$ how $=3$ (erişim tarihi: 02.03 .2021 ).

https://ketabpedia.com/\%D8\%AA\%D8\%AD\%D9\%85\%D9\%8A\%D9\%84/\%D8\%B1\%D8\%B4\%D9\%81-\%D8\%A7\%D9\%84\%D8\%B6\%D8\%B1\%D8\%A8-\%D9\%81\%D9\%8A-\%D8\%B4\%D8\%B1\%D8\%AD-\%D9\%84\%D8\%A7\%D9\%85\%D9\%8A\%D9\%87-\%D8\%A7\%D9\%84\%D8\%B9\%D8\%B1\%D8\%A8\%D8\%9B\%D8\%A7\%D8\%A8\%D9\%88\%D8\%A7\%D9\%84\%D8\%A8\%D8\%B1\%D9\%83/ (erişim tarihi: 02.03.2021). 